\title{
GROUND WATER IN CARBONATE ROCKS AND REGOLITH IN THE FAIRVIEW AREA, TENNESSEE
}

Charles R. Burchett, Ann Zurawski, Ann K. Sparkes, and Este F. Hollyday

U.S. GEOLOGICAL SURVEY

Water-Resources Investigations Report 83-4134

Prepared in cooperation with the

TENNESSEE DEPARTMENT OF CONSERVATION,

DIVISION OF WATER RESOURCES, and the

CITY OF FAIRVIEW

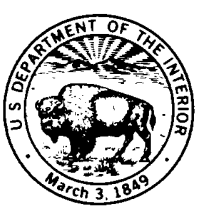

Nashville, Tennessee

1983 
UNITED STATES DEPARTMENT OF THE INTERIOR

JAMES G. WATT, Secretary

GEOLOGICAL SURVEY

Dallas L. Peck, Director

For additional information write to:

District Chief

U.S. Geological Survey A-413 Federal Building U.S. Courthouse

Nashville, TN 37203
Copies of this report can be purchased from:

Open-File Services Section

U.S. Geological Survey

Box 25425, Federal Center

Lakewood, CO 80225 


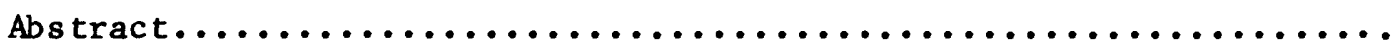

Introduction. .....................................

Geology ...........................................

Ground-water recharge, movement, and $d$ ischarge...............

Discharge at springs..............................

Discharge to streams..............................

Ground-water occurrence..............................

Supply-wel1 records..............................

Results of test drilling...........................

Discussion of test-well results.....................

Aquifer tests......................................

Eight-hour tests................................

Sevent $y-t w o$ hour tests...........................

Discussion of aquifer tests........................

Ground water quality...............................

Summary and conclusions..............................

References........................................ 


\section{ILLUSTRATIONS}

1. Map showing location of the Fairview area............

2. Map showing distribution of geologic formations

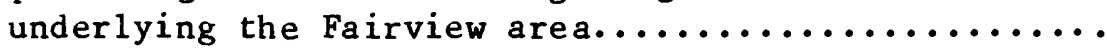

3. Diagram showing ground-water circulation in the

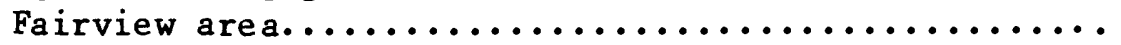

4. Map showing location of measured springs in the Fairview area............................ 8

5. Map showing location and relative value

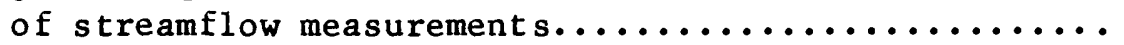

6. Graph showing plot of streamflow versus distance from

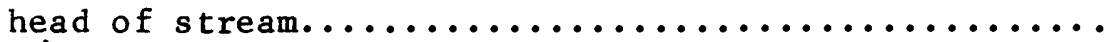

7. Graphs showing reported yields, depths, casing lengths, and topographic settings for wells in

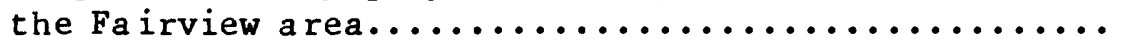

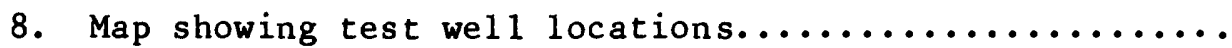

9. We11 logs showing pertinent geologic and hydrologic

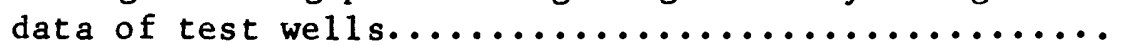

10. Sketch comparing the typical section of material penetrated by wells in the Fairview area to a

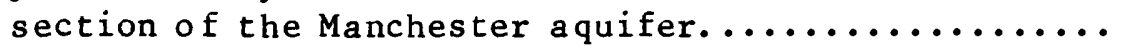

11. Graph showing water level and pumping rate during

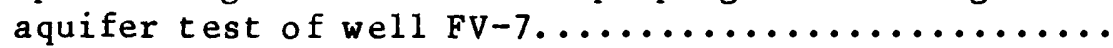

12. Graph showing water level and pumping rate during

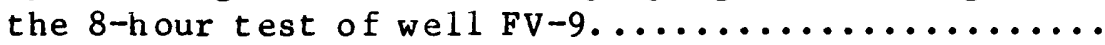

13-18. Graphs showing:

13. Water level and pumping rate during test

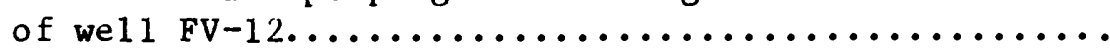

14. Water level and pumping rate during the 72 -hour

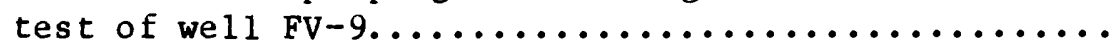

15. Relation between drawdown and $d$ istance during

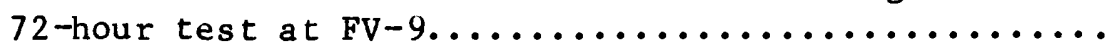

16. Water level and pumping rate during test of FV $-13 \ldots \ldots . .28$

17. Relation between drawdown and yield for half-hour pumping steps of $\mathrm{FV}-9 . \ldots \ldots \ldots \ldots \ldots \ldots \ldots \ldots \ldots \ldots \ldots \ldots \ldots$

18. Relation between specific conductance and occurrence of gypsum in test wells.....................

TABLES

Table 1. Discharge of springs in the Fairview area, Tennessee....

2. Discharge measurements of Horntavern and Morgan Springs

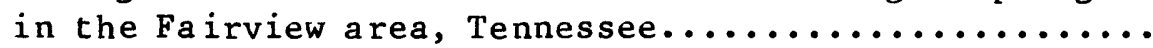

3. Geologic and hydrologic data for test wells

FV-1 through FV -14 in the Fairview area, Tennessee.....

4. Performance of pumped wells and estimates of potential

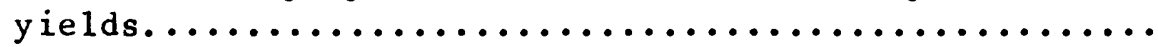

5. Waterquality data for water from four test wells in the Fairview a rea, Tennessee.............. 


\section{ABBREVIATIONS AND CONVERSION FACTORS}

Factors for converting inch-pound units to International system of units (SI) and abbreviation of units

\section{Multiply}

$$
\text { inch (in.) }
$$$$
\text { foot }(f t)
$$$$
\text { mile (mi) }
$$$$
\text { square mile }\left(\mathrm{mi}^{2}\right)
$$$$
\text { cubic foot }\left(\mathrm{ft}^{3}\right)
$$$$
\text { gallon per minute (gal/min) }
$$$$
\text { million gallons per day (Mgal/d) }
$$$$
\text { pound ( } 1 b \text { ) }
$$

ton

micromho per centimeter

at $25^{\circ}$ Celsius ( $\mu \mathrm{mho} / \mathrm{cm}$ )

\section{By \\ To obtain}

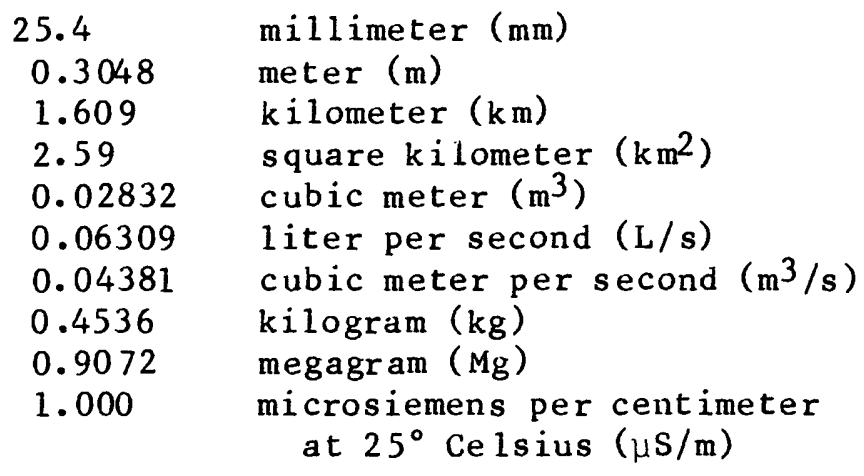

25.4

0.3048

1.609

millimeter $(\mathrm{mm})$

meter (m)

2.59

0.02832

kilometer $(\mathrm{km})$

square $\mathrm{kilometer}\left(\mathrm{km}^{2}\right)$

0.06309

cubic meter $\left(\mathrm{m}^{3}\right)$

0.04381

liter per second ( $\mathrm{L} / \mathrm{s})$

0.4536

cubic meter per second $\left(\mathrm{m}^{3} / \mathrm{s}\right)$

0.9072

kilogram ( kg)

megagram ( $\mathrm{Mg})$

1.000

$$
\text { at } 25^{\circ} \text { Celsius }(\mu \mathrm{S} / \mathrm{m})
$$

Temperature in degrees Fahrenheit $\left({ }^{\circ} \mathrm{F}\right)$ can be converted to degrees Celsius $\left({ }^{\circ} \mathrm{C}\right)$ as follows:

$$
{ }^{\circ} \mathrm{F}=1.8{ }^{\circ} \mathrm{C}+32
$$

National Geodetic Vertical Datum of 1929 (NGVD of 1929).--A geodetic datum derived from a general adjustment of the first-order level nets of both the United States and Canada, formerly called mean sea level. NGVD of 1929 is referred to as sea level in this report. 


\title{
GROUND WATER IN CARBONATE ROCKS AND REGOLITH
}

\author{
IN THE FAIRVIEW AREA, TENNESSEE
}

Charles R. Burchett, Ann Zurawski, Ann K. Sparkes, and Este F. Hollyday

\begin{abstract}
Fourteen test wells drilled in the Fairview area, Tennessee, produce from 3 to 100 gallons per minute and have an average yield of 32 gallons per minute; yields were measured while blowing water from the wells with compressed air. In comparison, the average yield of 134 supply wells reported by drillers is 13 gallons per minute. Specific capacities for three of the test wells ranged from 0.3 to 0.6 gallons per minute per foot of drawdown after 8 hours of pumping at 20 to $47 \mathrm{gallons}$ per minute. Two test wells had specific capacities of 1.1 and 0.4 gallons per minute per foot of drawdown after 72 hours of pumping at 55 and 43 gallons per minute.

The mineral content of ground water increases greatly below a gypsum horizon approximately 100 feet below the top of the Fort Payne Formation. Ground water above the gypsum horizon, however, meets the regulatory standards for drinking water served to the public.
\end{abstract}

\section{IN TRODUCT ION}

A variety of water sources that $c$ an be developed economically are needed to satisfy a growing demand for municipal and industrial water in Middle Tennessee. The interest of water managers in alternative water sources has emphasized a lack of information on the occurrence of ground water in carbonate rocks. These rocks have been used, for the most part, as sources for rural, domestic water supply. Development for municipal and industrial supplies is deterred by the highly variable water-bearing properties of these rocks; low-yielding wells are common, and the development potential for large supplies is unpredictable. A better understanding of the ground-water hydrology would do much to diminish the uncertainty of locating large ground-water supplies.

A study of ground-water in the Fairview area beginning in Fal1 1979 and ending spring 1981 was conducted by the U.S. Geological Survey, in cooperation with the city of Fairview and the Tennessee Division of Water Resources. This particular study is part of a larger study of the carbonate rocks of the Highland Rim in which concepts of ground-water occurrence are being tested in specific sites. The objectives of the study at Fairview were to acquire data on the quantity, quality, and geologic occurrence of ground water and to define the ground-water hydrology in the area. The study included analysis of available data on the geology, wells, springs, water quality, and collection and analysis of data on the low flow of 
streams. This analysis was followed by drilling test wells to sample the rock sequence, pumping wells to estimate the quantity of water that could be produced, and analyzing water samples to determine the ground-water quality.

The Fairview area ( $f i g .1$ ) is in Williamson County in Middle Tennessee. The 104-square-mile study area lies on the rolling plateau of the Highland Rim, a section of the Interior Low Plateaus physiographic province. The Fairview area is on a $\mathrm{T}$-shaped ridge roughly defined by Highways 100 and 96. Surface drainage is in all directions. The major streams are the South Harpeth River which drains the eastern part of the area, and Turnbull Creek which drains the western part. Local relief is about $200 \mathrm{feet}$ and maximum relief throughout the area is about 400 feet.

\section{GEOLOGY}

The distribution of the geologic formations underlying the Fairview area is shown on geologic maps published by the Tennessee Division of Geology for Fairview, Kingston Springs, White Bluff, and Craigfield quadrangles ( $\mathrm{fig} .2$ ). The Mississippian bedrock consists of limestone some of which has been partly replaced by quartz, and of chert, siltstone, and dolomite.

The Warsaw Formation caps the hills and ridges in the Fairview area. In some places the thickness of weathered and unweathered Warsaw is as much as 120 feet. Almost everywhere, it is partly or completely weathered to dense clay regolith (soil and weathered rock) with angular blocks of porous limestone or dolomite composed of fossil fragments replaced by silica. The regolith is yellowish to reddish brown. Where unweathered, the Warsaw Formation occurs in thick beds and is 1 imestone or 1 imestone partly replaced with quartz which is composed of sand-sized fragments of fossils. The unweathered rock is 1 ight gray.

Underlying the Warsaw Formation is the Fort Payne Formation which is 200 to 250 feet thick. The Fort Payne weathers to a clay-rich regolith that occasionally contains rock rubble above the bedrock. In the unweathered state, the Fort Payne Formation can be subdivided into three distinct facies or appearances. These facies consist of 1 imestone characterized by coarse, sand-sized fragments of fossils, limestone or dolomite composed of fine sand-sized fragments, and a siltstone composed of silt-sized dolomite crystals. The latter two facies usually contain fine-sand to silt-size quartz grains. Contacts between facies are gradational. Chert ( 1 imestone or dolomite replaced by silica) occurs throughout the formation in distinct beds, some beds as thick as 14 inches, and in irregular discontinuous beds and nodules. Chert-lined cavities containing quartz, calcite, or gypsum are present throughout the formation.

The coarse-grained 1 imestone facies is as much as 20 feet thick and generally occurs near the top of the formation. Locally it may be present near the base of the formation. It consists of fossils, principally crinoids and brachiopods, surrounded by clay-to-silt-sized particles of calcite and quartz. Beds and nodules of light-gray chert containing minute 


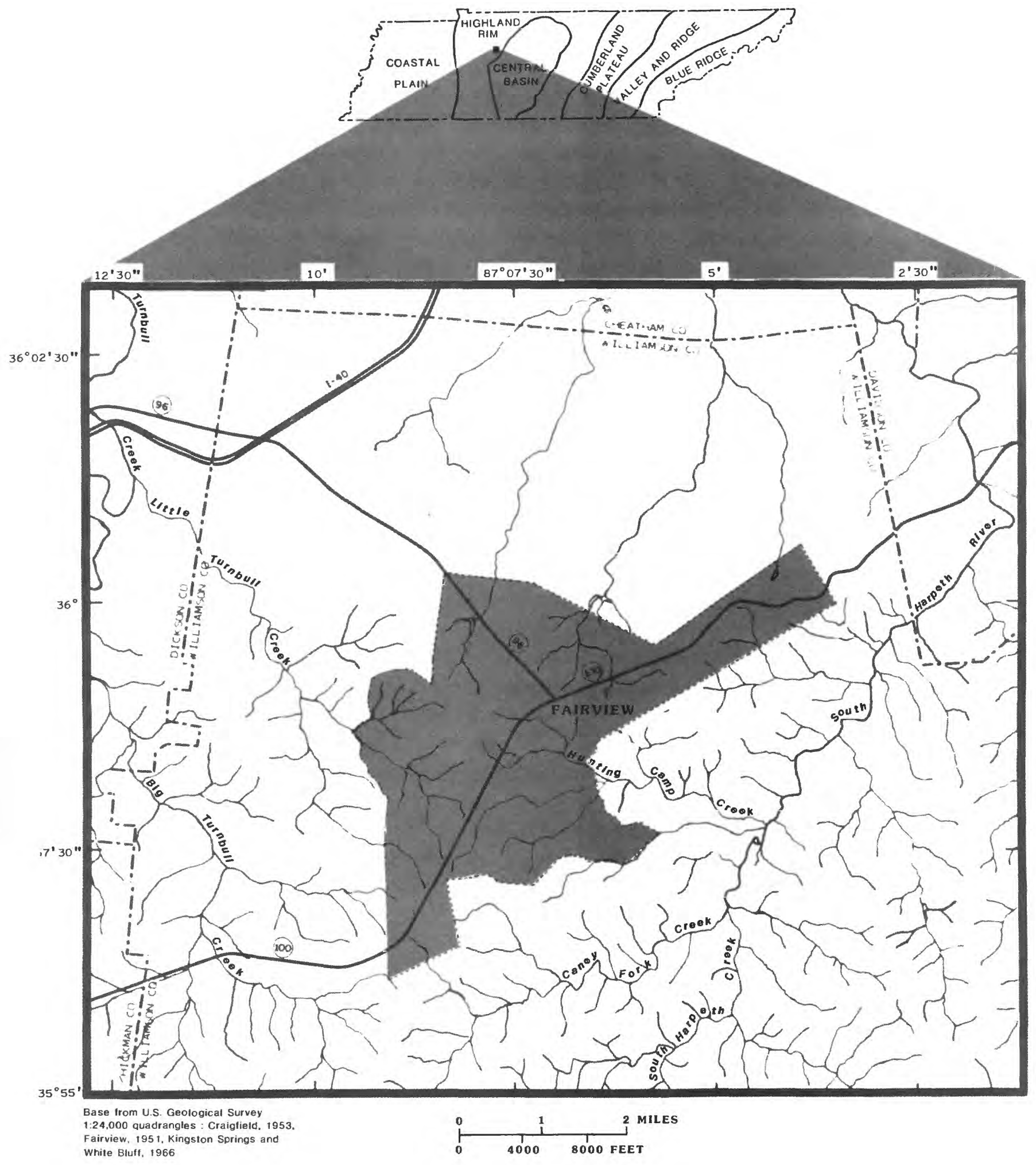

Figure 1.--Location of the Fairview area. 

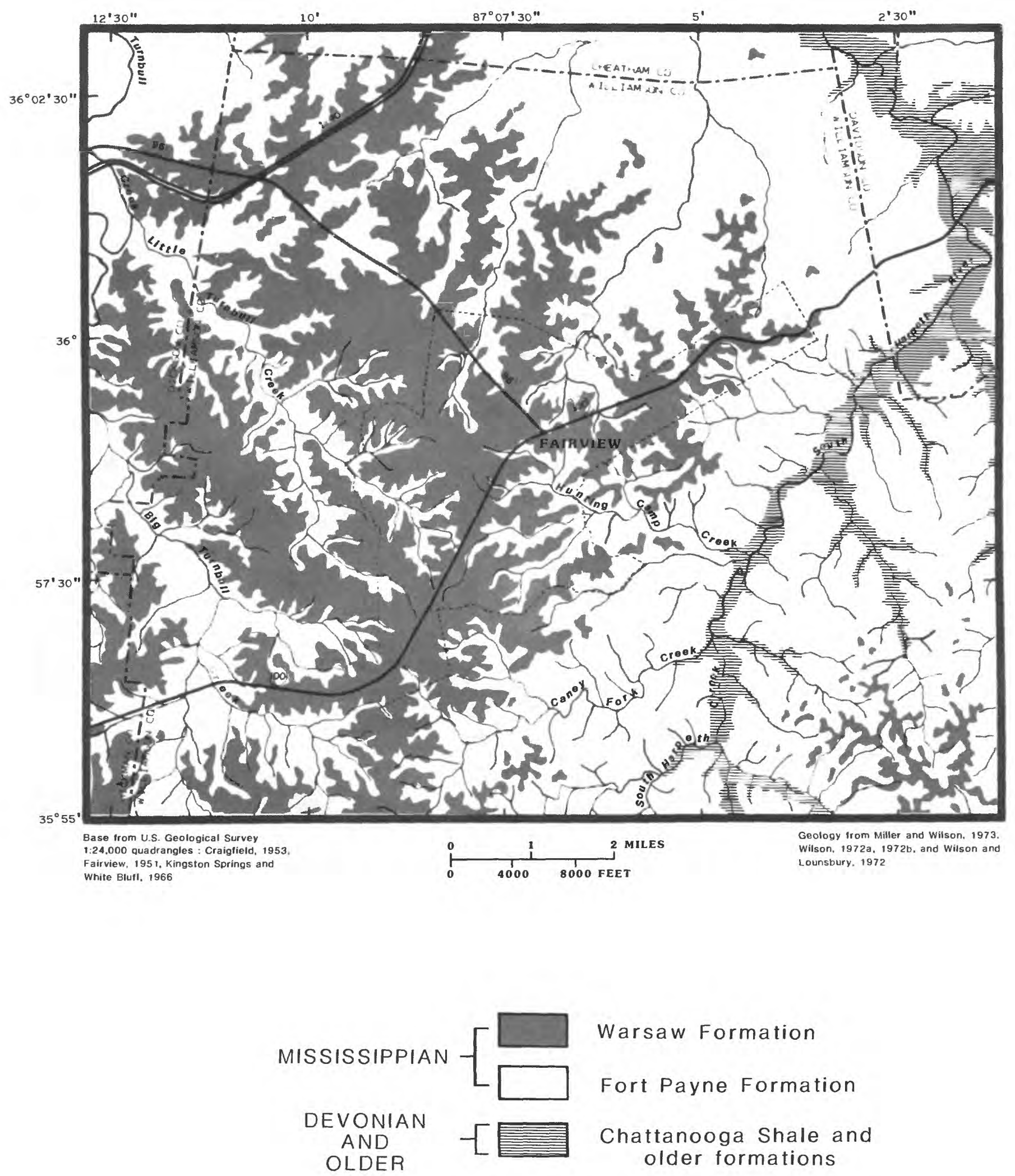

Figure 2.--Distribution of the geologic formations underlying the Fairview area. 
dark-gray fossils occur within this facies. Common accessory minerals are pyrite, glauconite, and some gypsum which occurs in marble- to egg-size nodules. The unweathered rock of this facies is 1 ight gray.

The fine-grained limestone or dolomite facies occurs in the upper onethird to one-half of the Fort Payne Formation. It surrounds the coarsegrained limestone facies where this latter facies occurs near the top of the formation. The fine-grained 1 imestone or dolomite facies rarely contains large fossil fragments; minute fossil fragments are present in mediumgray chert associated with the 1 imestone. The unweathered rock is 1 ight gray. Small amounts of pyrite and gypsum are present.

The siltstone facies occupies the lower part of the formation. It contains many small cavities filled with gypsum and larger openings lined with gypsum. Pyrite is an accessory mineral in this facies.

Underlying the Fort Payne Formation is the Devonian Chattanooga Shale, a fissile black shale approximately 20 feet thick. Below the shale is a thick sequence of older formations consisting of Silurian and Ordovician limestone. The Chattanooga Shale and older formations crop out in the study area only in the valley of the South Harpeth River (fig. 2).

The rocks in the Fairview area dip to the northwest at about 11 feet per mile away from the axis of the Nashville Dome, which is 40 miles southeast of the Fairview area. Small-scale folds are superposed on this regional structure; however, lack of subsurface information has hindered mapping of these folds. Although there are no known faults in the Fairview area, numerous joints, or nearly vertical fractures, occur in the rock and are visible in roadcuts and other rock exposures.

\section{GROUND-WATER RECHARGE, MOVEMENT, AND DISCHARGE}

About two-thirds of the precipitation in the Fairview area either evaporates or is taken up by plants and transpired to the atmosphere. The remaining one-third becomes streamflow. Half of this remaining third is direct runoff that occurs during storms when the soil is saturated. The other half is water that has soaked into the ground and moved down past the root zone to recharge the ground-water reservoir. Ground water fills pore spaces in the regolith and crevices in the rock to a level (the water table) that fluctuates in response both to recharge and to natural discharge. Recharge causes the water level to rise; natural discharge causes the water level to fall. Water levels are highest in early spring prior to the growing season, and lowest in fall following 1 ittle or no recharge during the growing season and a long period of natural discharge.

Recharge occurs throughout most of the Fairview area but is probably concentrated in the upland areas. Water moves from the uplands to discharge at springs and seeps in the valleys. This ground-water discharge sustains the flow of streams during dry weather. Although ground water occurs in tiny crevices in the rock to depths of several hundred feet, at least ninetenths of the fresh ground water in circulation occurs above the altitude of the major streams. Most of the ground-water circulation ( $f$ ig. 3) occurs 


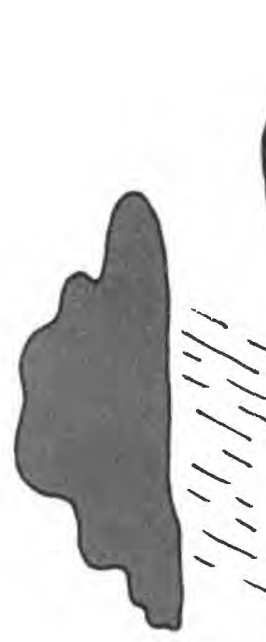

\section{$\Gamma$}

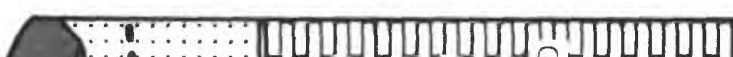

:

: :

: : :

(a) U.

:

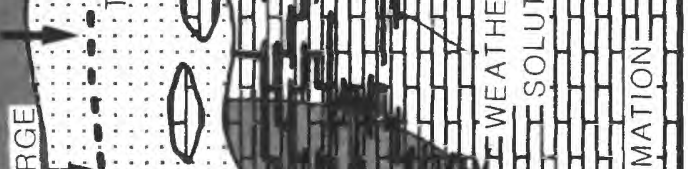

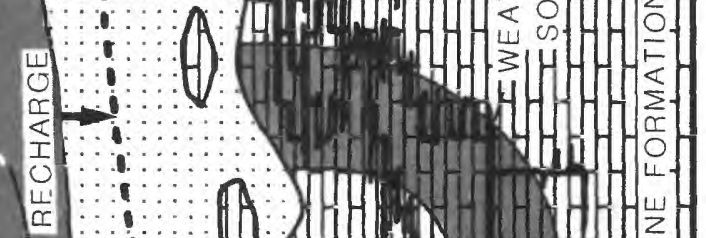

ㅁ.

$\rightarrow$ OAf
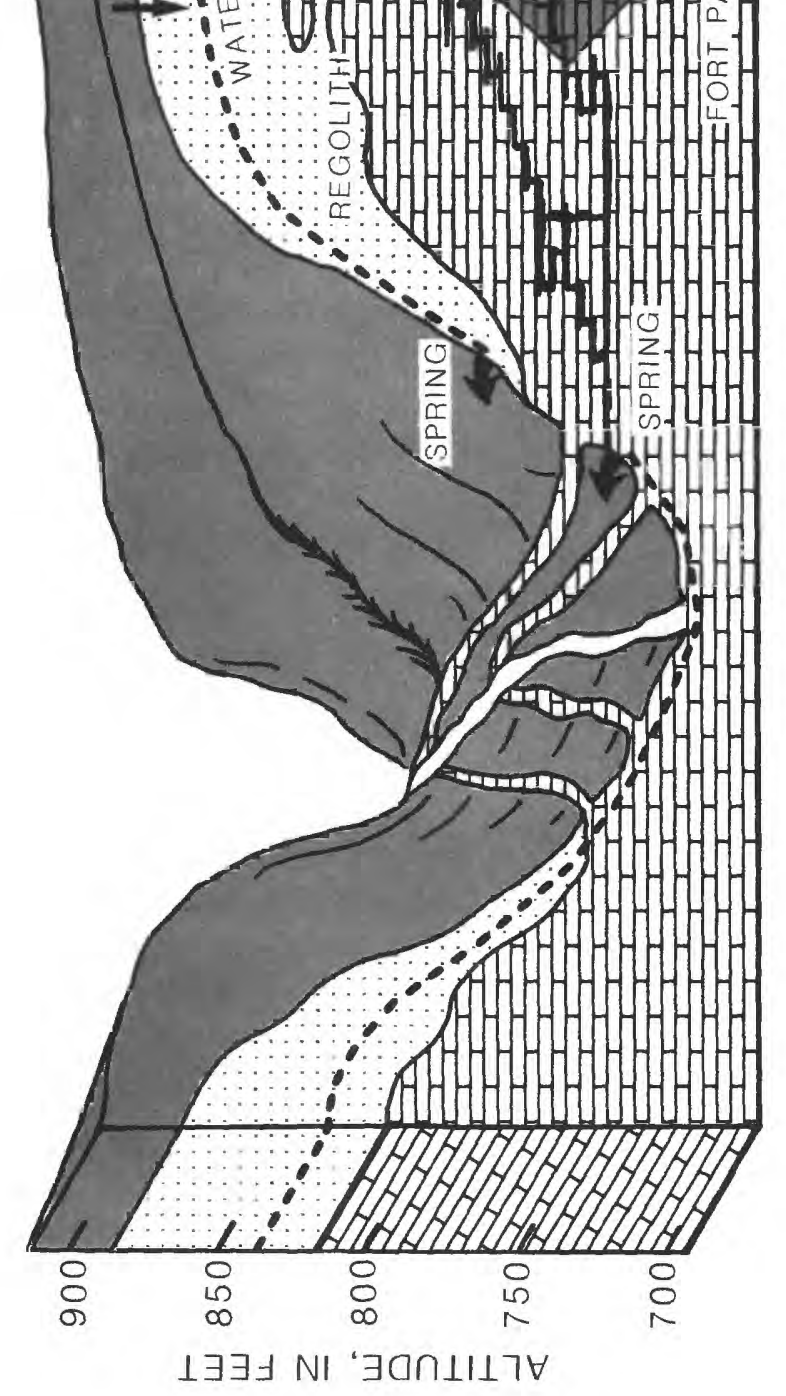

골

$>\frac{2}{2}$

$\stackrel{5}{0}$

$\mp$

5

$\infty \pm$

on

ह क

क $\exists$

$+20$

0 로 을

o n

$\leftarrow 0$

- 0 ह

का?

ป क

0 은

$-\doteq$

E

흘 즐

on 0

ह

$\stackrel{2}{\leftarrow}$

s)

3 : 3

ह 는

ㅇำ

i

$3:$

$\therefore$ os

30

$\because 00$

단

Е

들 눈

क 5

2) 0

\%

$3 E$

ङ

0

मे ह

in 
within the regolith and upper 100 feet of the Fort Payne Formation. Discharge is at springs in the upland valleys at altitudes of approximately 720 to 760 feet where bedrock often is exposed in the streambed.

\section{Discharge at springs}

Springs in the Fairview area are of two types. One type discharges from the regolith on the valley walls. These springs usually cease flowing during sustained hot dry periods. The other type discharges from the bedrock in the valley floors. The flow of seven valley-floor springs was measured or estimated July 31, 1979 ( $\mathrm{fig}$. 4). Al1, except Mayfield Spring and Basin Spring, discharge from the upper 80 feet of the Fort Payne Formation. The average flow of the five Fort Payne springs on July 31 was $112 \mathrm{gal} / \mathrm{min}$ (gallons per minute). In contrast, Mayfield Spring and Basin Spring, which discharge from a few feet below the base of the Chattanooga Shale, had an average flow of only about 2 gal/min.

There is a considerable range in the discharge of these seven springs, as shown in Table 1 . On July 31, 1979, one spring was dry, two were flowing less than $5 \mathrm{gal} / \mathrm{min}$. The largest flow was $310 \mathrm{gal} / \mathrm{min}$. The average flow of the springs was $81 \mathrm{gal} / \mathrm{min}$.

Table 1.--Discharge of springs in the Fairview area, Tennessee

\begin{tabular}{|c|c|c|}
\hline Name & Date & $\begin{array}{l}\text { Discharge, } \\
\text { in gallons } \\
\text { perminute }\end{array}$ \\
\hline Morgan Spring & $\begin{array}{r}12-19-69 \\
7-31-79\end{array}$ & $\begin{array}{l}140 \\
310\end{array}$ \\
\hline Chester Spring & $\begin{array}{l}5-12-67 \\
6-13-67 \\
7-31-79\end{array}$ & $\begin{array}{r}140 \\
50 \\
0\end{array}$ \\
\hline $\begin{array}{l}\text { Un named spring } \\
\text { near Cunningham } \\
\text { Cemetery. }\end{array}$ & $7-31-79$ & $1_{110}$ \\
\hline Horntavern Spring & $7-31-79$ & 2120 \\
\hline Quinn Spring & $7-31-79$ & $1_{20}$ \\
\hline Basin Spring & $7-31-79$ & 14.0 \\
\hline Mayfield Spring & $7-31-79$ & $1_{1}$ \\
\hline
\end{tabular}

1Estimated.

${ }^{2}$ Includes $65 \mathrm{gal} / \mathrm{m}$ in pumpage by the city of $\mathrm{Fairview}$. 


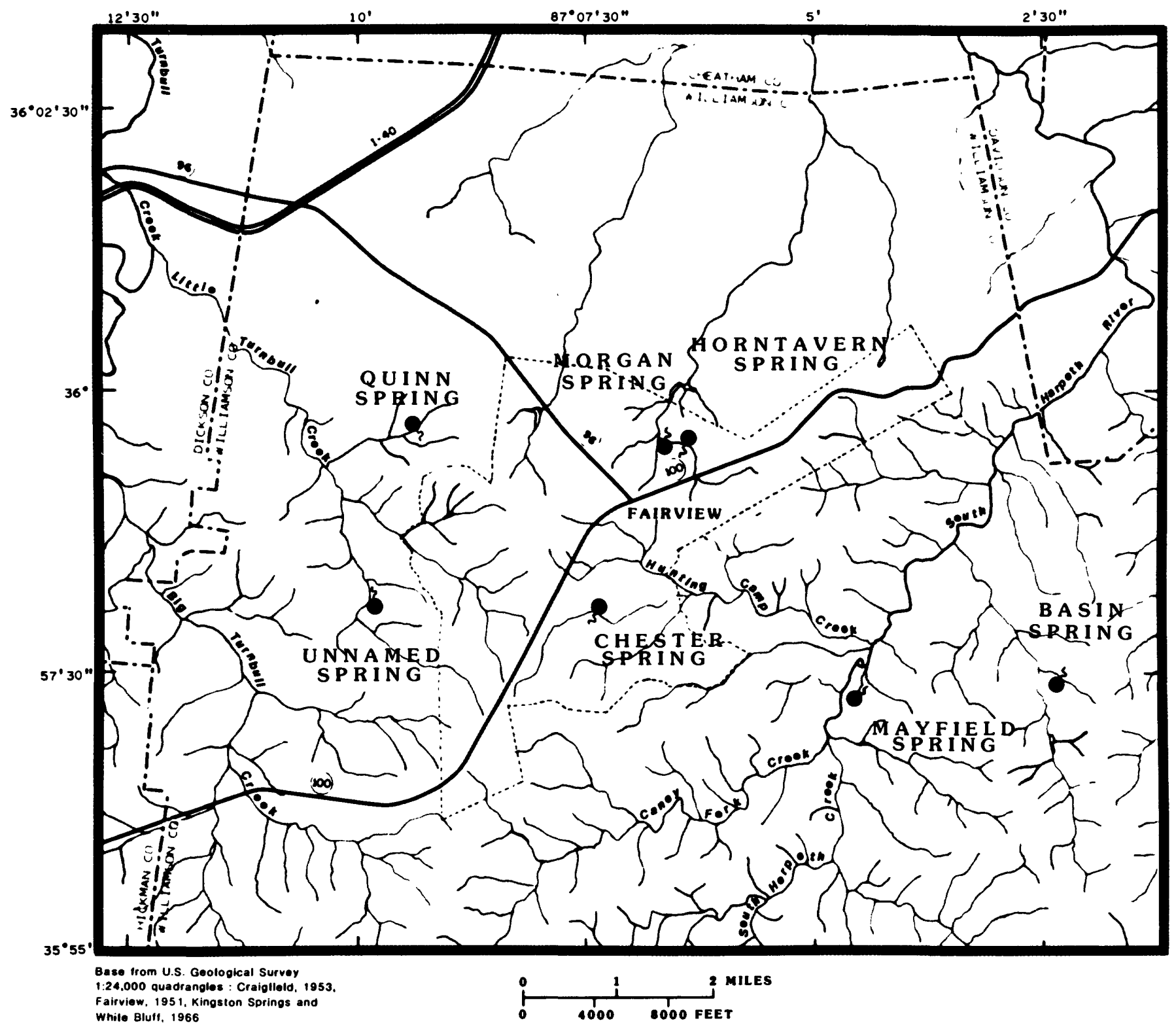

Figure 4.--Locations and names of springs measured in the Fairview area. 
Some spring discharges vary considerably with the seasons. Chester Spring, discharged $140 \mathrm{gal} / \mathrm{min}$ on May 12, 1967, but was not flowing on Ju1y 1, 1979. Horntavern Spring, however, is reported to have a minimum yield of $65 \mathrm{gal} / \mathrm{min}$ (Fairview City Manager, written commun., 1979) and provides a dependable source of water that supplies about 60 percent of the water used by the city of Fairview. The discharge of Horntavern and Morgan Springs have been measured 11 times within a period of several years, but most of these measurements were made during 1980-81. Discharge at Horn-

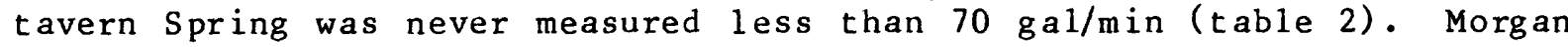
and Horntavern Springs seem to have uncommonly constant flow with the maximum measured discharge being less than three times the minimum measured discharge.

Table 2.--Discharge measurements of Horntavern and Morgan Springs in the Fairview area, Tennessee

\begin{tabular}{|c|c|c|}
\hline & Horntavern Spring & Morgan Spring \\
\hline Date & $\begin{array}{l}\text { Di scharge, } \\
\text { in gallons } \\
\text { per minute* }\end{array}$ & $\begin{array}{l}\text { Di scharge, } \\
\text { in gallons } \\
\text { per minute }\end{array}$ \\
\hline $12-19-69$ & -- & 140 \\
\hline $7-31-79$ & 120 & 310 \\
\hline $10-14-80$ & 80 & 110 \\
\hline $11-12-80$ & 70 & 110 \\
\hline $12-22-80$ & 80 & $-\infty$ \\
\hline $2-02-81$ & 120 & 190 \\
\hline $2-23-81$ & 80 & 130 \\
\hline $4-13-81$ & 110 & 160 \\
\hline $5-21-81$ & 120 & 160 \\
\hline $6-29-81$ & 115 & 130 \\
\hline $9-08-81$ & 90 & 140 \\
\hline
\end{tabular}

*Includes at least $65 \mathrm{gal} / \mathrm{min}$ pumpage by the city of Fairview.

\section{Discharge to Streams}

Low-flow discharge measurements were made July 31,1979 , in the Fairview area to determine the amount of ground-water discharge to the streams. The measurement sites included the parts of the South Harpeth River, Brush Creek, and Turnbul1 Creek basins that are within the study area. These three streams head in the upland areas and have channels cut down through the regolith and the Fort Payne Formation in their descent to the deep, major valleys. They are supplied during periods of base flow by ground-water discharge from the regolith and Fort Payne bedrock. 
Stream discharge increases downstream in part as a function of the drainage area. Dividing the discharge by the drainage area, however, reveals some variation in the downstream.contribution per square mile of additional drainage area. Average streamflow was $0.65\left(\mathrm{ft}^{3} / \mathrm{s}\right) / \mathrm{mi}^{2}$ (cubic feet per second per square mile), yet values range from as little as $0.10\left(\mathrm{ft}^{3} / \mathrm{s}\right) / \mathrm{mi}^{2}$ in the headwaters of Hunting Camp Creek to a maximum of $1.05\left(\mathrm{ft}^{3} / \mathrm{s}\right) / \mathrm{mi}^{2}$ at one point along South Harpeth River. Figure 5 shows the measurement sites, indicating those that were dry, those with below average flow, and those with above average flow per square mile.

In general, the ground-water contribution to four of the six major streams is small in the headwaters and increases to a maximum at some point between 2 and 4 miles downstream (fig. 6). These streams have cut down through the regolith and upper part of the Fort Payne Formation along these headwater reaches. Al1 values of $1.00\left(\mathrm{ft}^{3} / \mathrm{s}\right) / \mathrm{mi}^{2}$ or more were measured within a reach 1.5 to 4.5 miles from the head of the stream. Contributions diminished slightly with distance downstream, as shown in figure 6 , indi- cating more ground-water discharge in the upstream areas, from the upper part of the Fort Payne.

If the average contribution of $0.65\left(\mathrm{ft}^{3} / \mathrm{s}\right) / \mathrm{mi}^{2}$ is assumed to represent a minimum ground-water discharge, then at least 16,000 million gallons of ground water is discharged annually from the 104-square-mile area. If recharge is assumed to occur largely on the uplands, which occupy approximately half of the area, annual recharge rates could be as much as $1.3\left(\mathrm{ft}^{3} / \mathrm{s}\right) / \mathrm{mi}^{2}$ or $0.9(\mathrm{Mgal} / \mathrm{d}) / \mathrm{mi}^{2}$ of upland.

\section{GROUND-WATER OCCURRENCE}

\section{$\underline{\text { Supply-We11 Records }}$}

Since 1963, records of new water-supply wells in Tennessee have been reported to the Division of Water Resources by State-licensed water-well drillers. Each record includes information on total depth of the well, regolith thickness, depth to the water-bearing openings, and estimated well yield. Records of 139 supply wells have been reported from the Fairview area. Most of these records pertain to wells that supply water for domestic use.

Depths of reported supply wells average 135 feet but range from 35 to 651 feet. However, 84 percent of the wells are between 50 and 199 feet deep (fig. 7). Casing depths in the wells range from 11 to $187 \mathrm{feet}$ and have a mean of 52 feet. Seventy-five percent of the supply wells are on a hilltop or slope.

Average yield for supply wells in the Fairview area is $13 \mathrm{gal} / \mathrm{min}$. The maximum reported yield is $70 \mathrm{gal} / \mathrm{min}$ and three of these wells are reported to be dry. Eighty-four percent of the supply wells yield more than $2 \mathrm{ga} / \mathrm{min}$ and 31 percent are reported to yield $20 \mathrm{gal} / \mathrm{min}$ or more. Supply wells that produce $20 \mathrm{gal} / \mathrm{m}$ in or more are generally on slopes. They obtain water in most cases, from between 50 and 150 feet below land surface. Supply wells producing $2 \mathrm{gal} / \mathrm{min}$ or less are in all topographic positions. 


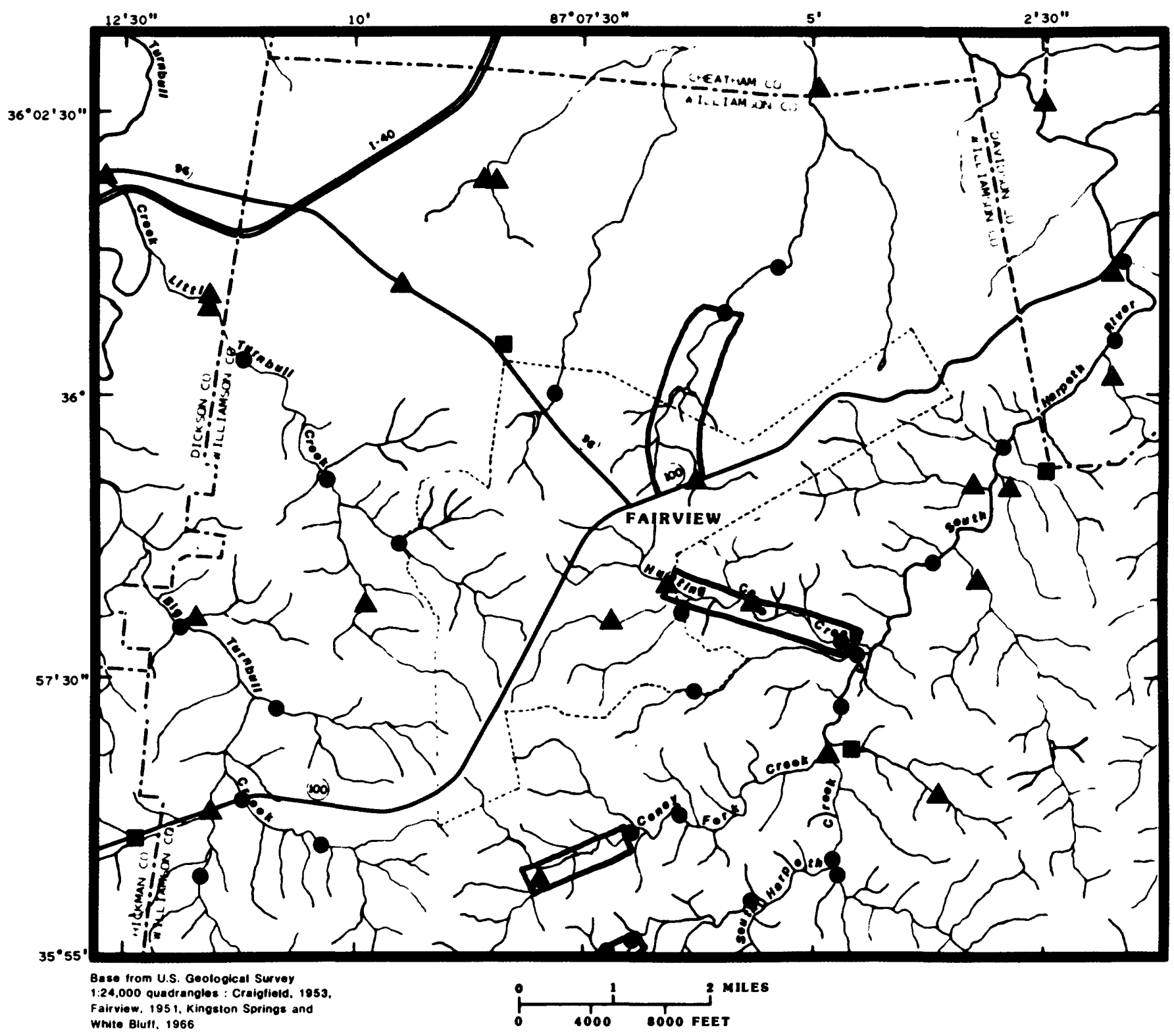

EXPLANATION

- Above average flow per square mile

Dry

$\triangle$ Below average flow per square mile

Gaining headwater reaches

Figure 5.--Location and relative value of streamflow measurements. 

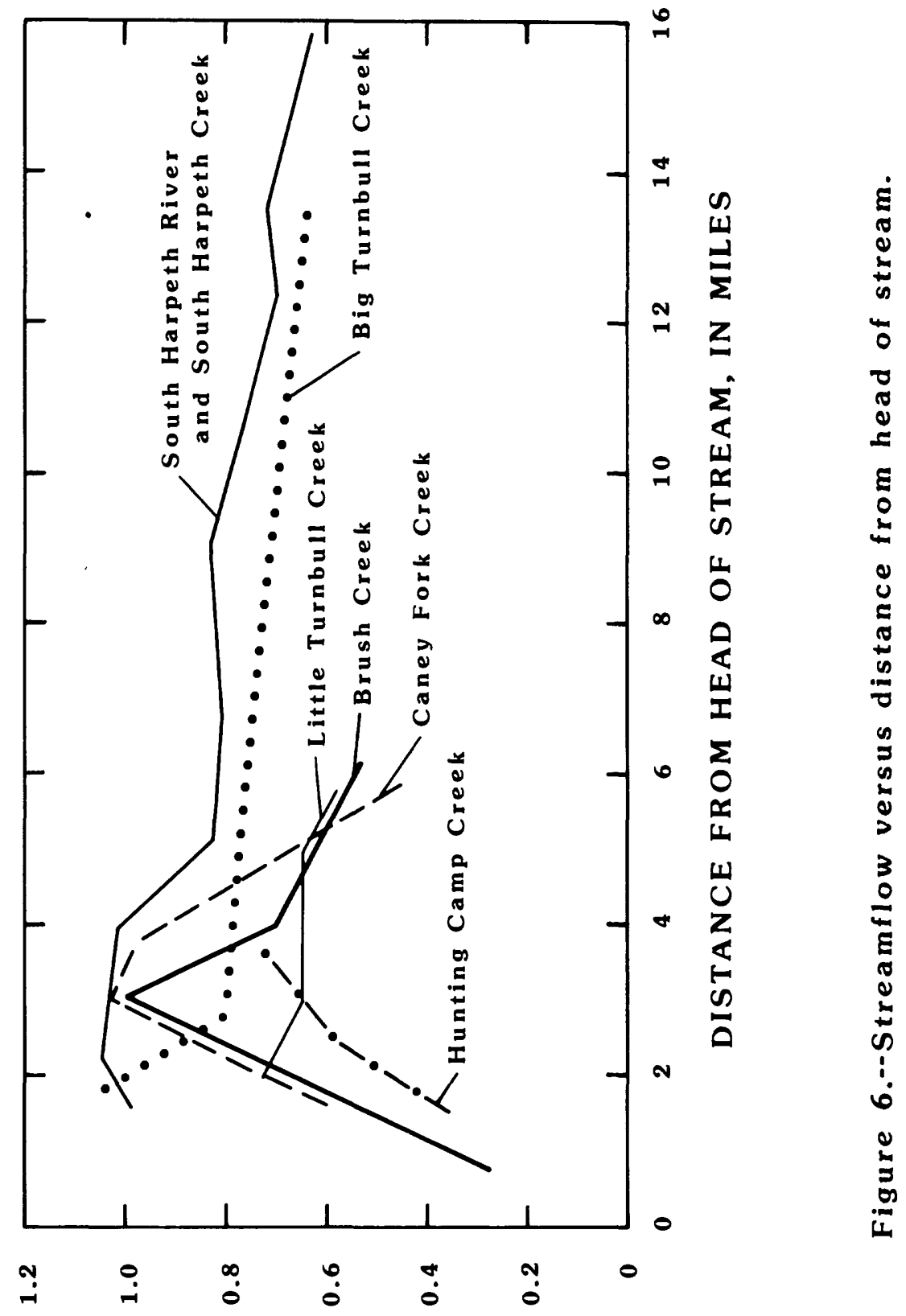

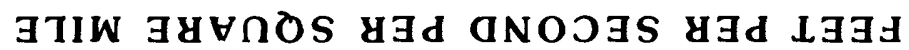
JIgno NI 'MOTHWHayLS daynSHaW 


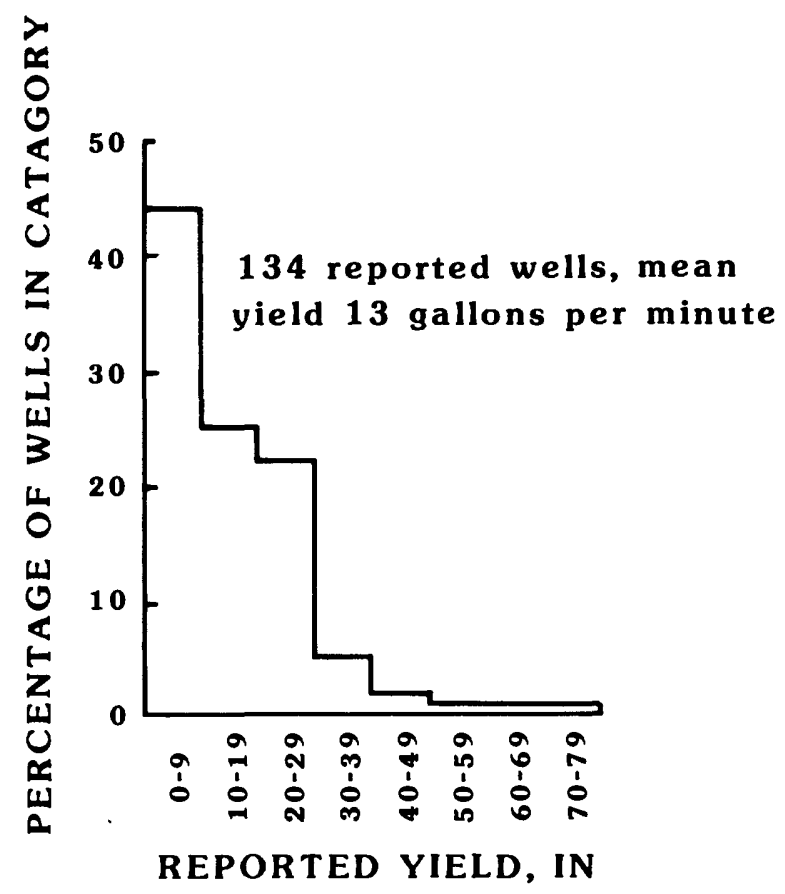

GALLONS PER MINUTE

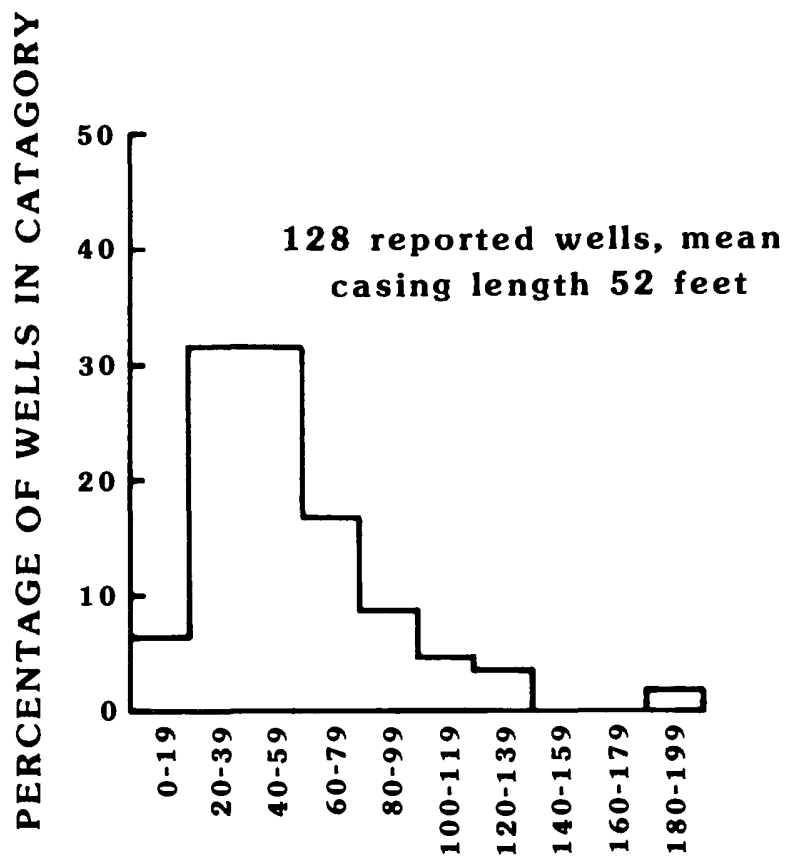

LENGTH OF CASING, IN FEET

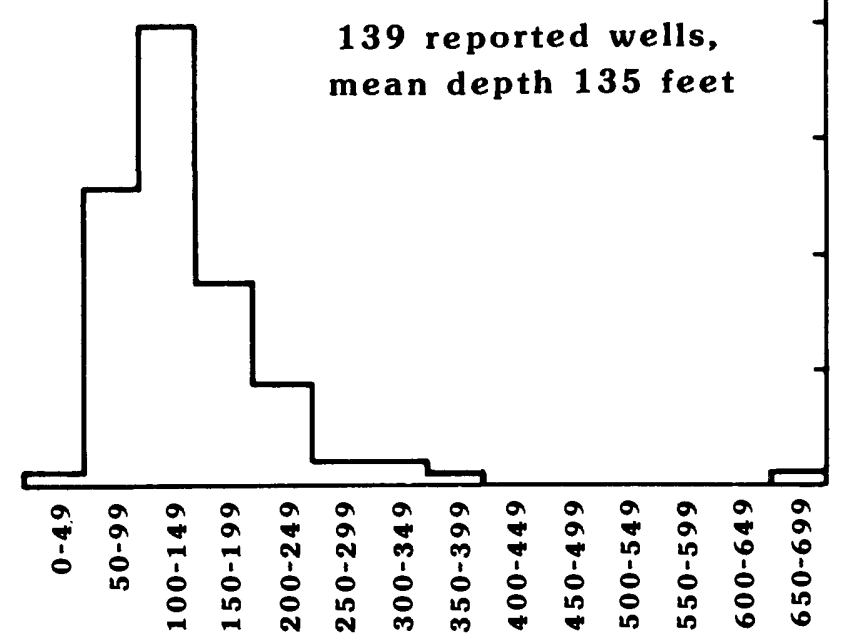

DEPTH OF WELL, IN FEET

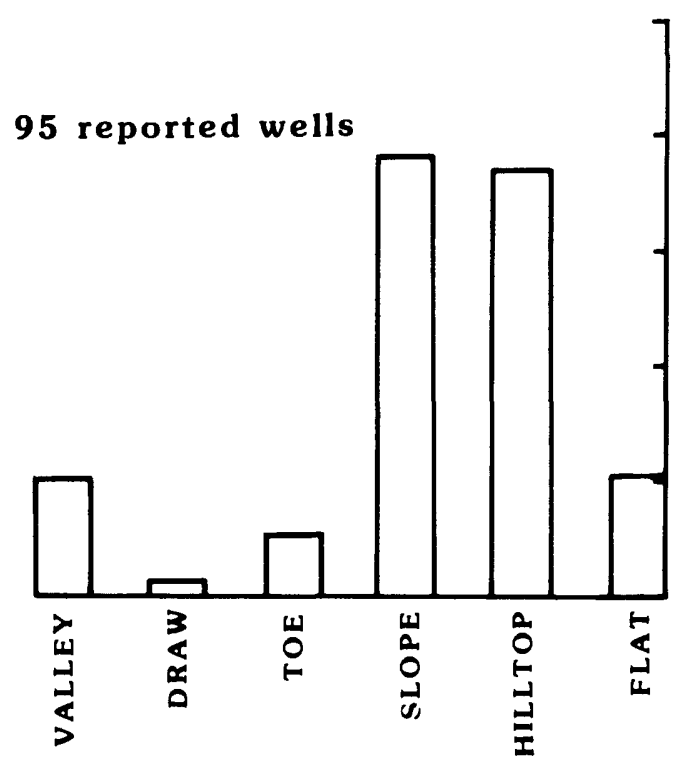

TOPOGRAPHIC SETTING

Figure 7.--Reported yields, depths, casing lengths, and topographic settings for wells in the Fairview area. Information obtained from Tennessee Division of Water Resources, July 25, 1979. 
They are commonly drilled deeper than other supply wells presumably in hopes of obtaining an adequate supply. The average depth of these wells is 190 feet as compared to $115 \mathrm{feet}$ for wells producing $20 \mathrm{gal} / \mathrm{m}$ in or more.

Supply wells in valleys or in upland draws have less casing and have lower yields than wells in other topographic situations. Three of the nine wells located in valleys were reported to yield water either containing hydrogen sulfide gas or having black-sulfide coloration, whereas only one of the wells in other locations yielded water containing noticeable sulfide.

\section{Results of Test Drilling}

Fourteen test wells were drilled in the Fairview area (fig. 8) between October 1979 and February 1981. The first five were drilled in gently sloping valleys or draws. The remainder were drilled on hills; three of these (FV-9, FV-10, and FV-14) are situated in a swale or shallow depression on a hilltop. Depths range from 90 to 285 feet and average about 185 feet. Thickness of regolith ranges from 3 feet in FV-4 to 97 feet in FV-8 and averages about 50 feet (table 3 and fig. 9). At the time they were drilled, the test wells produced between 3 and $100 \mathrm{gal} / \mathrm{min}$ and averaged 32 gal/min when blown with compressed air.

Ten of the test wells begin in the Warsaw Formation and penetrate the Fort Payne Formation. The Warsaw occurs only as regolith. The four other test wells begin in the Fort Payne. Only FV-1 is completed below the Fort Payne Formation in the Chattanooga Shale. Beds of gypsum in the middle of the Fort Payne Formation were penetrated by six test wells. The shallowest occurrence of gypsum ranges from 100 feet to 180 feet below land surface, corresponding to depths below the top of the Fort Payne Formation of approximately 90 to 190 feet.

Water-bearing openings occur at the base of the regolith in seven of the test wells; yields at the contact between regolith and bedrock range from 2 to $34 \mathrm{gal} / \mathrm{min}$ and average $13 \mathrm{gal} / \mathrm{min}$. This zone yielded $20 \mathrm{gal} / \mathrm{min}$ during the drilling of one well, but became completely clogged with mud during development. Water-bearing openings in the bedrock $r$ ange in depth from 7 to 216 feet below land surface, and may occur as deep as 200 feet below the top of bedrock. The number of water-bearing openings penetrated in the bedrock by each test well ranged from zero to five. Some waterbearing openings $c$ an be traced between wells a few hundred feet apart. Many water-bearing openings contain weathered rock having a characteristic brown color. Some water-bearing openings $c$ an be traced to weathered zones in nearby wells where they yield little or no water. This implies that water-bearing openings grade laterally along bedding planes first into weathered zones with little or no water and then into unweathered rock in distances of a few hundred feet. The thickness of water-bearing openings in the bedrock ranges from about 1 inch in several test wells to 3.5 feet in FV-5. This large opening is almost completely filled with mud and yields less than $5 \mathrm{gal} / \mathrm{min}$. 


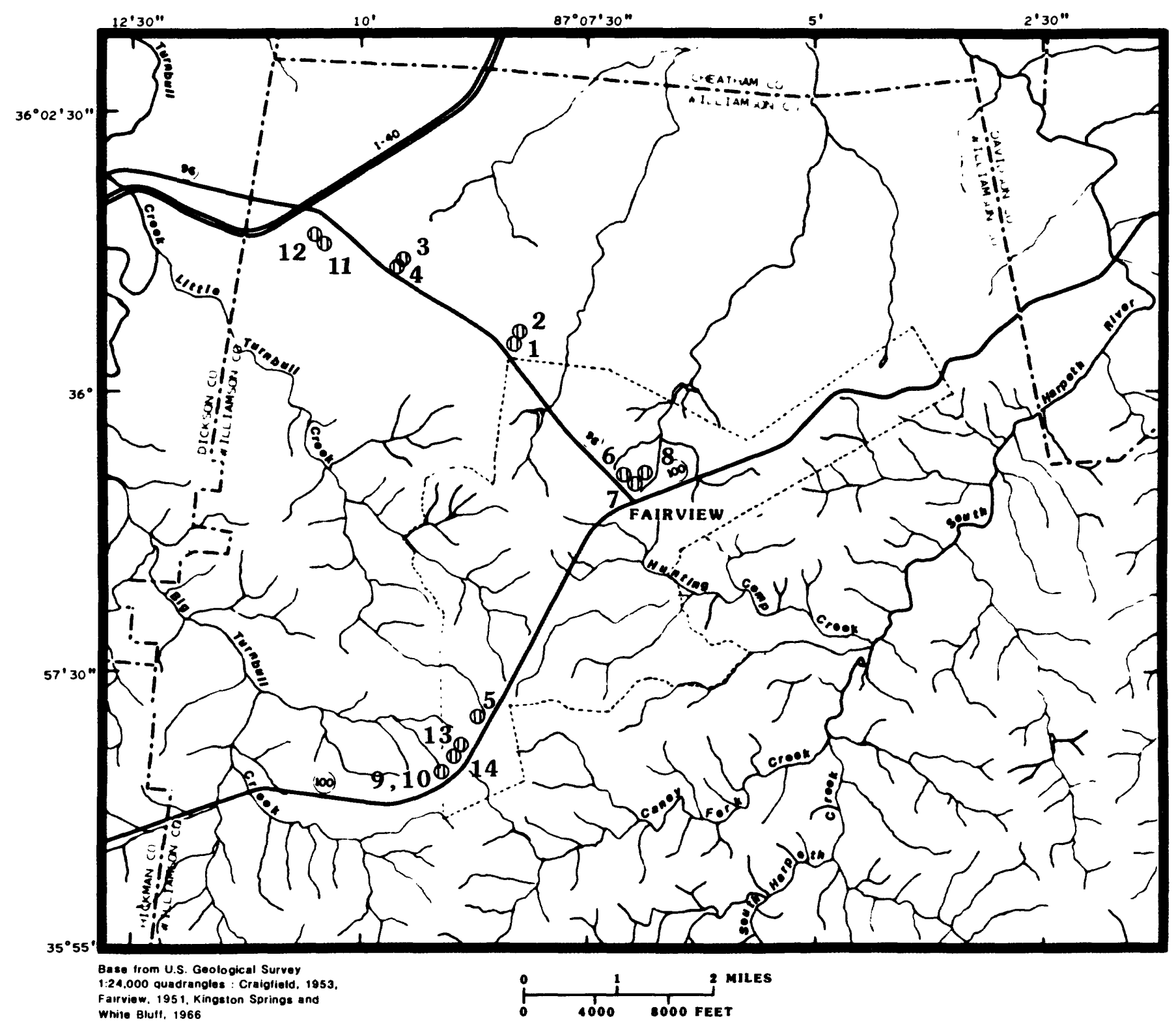

EXPLANATION

(1) Well and number

( $F V$ - not shown)

Figure 8.--Test well locations. 


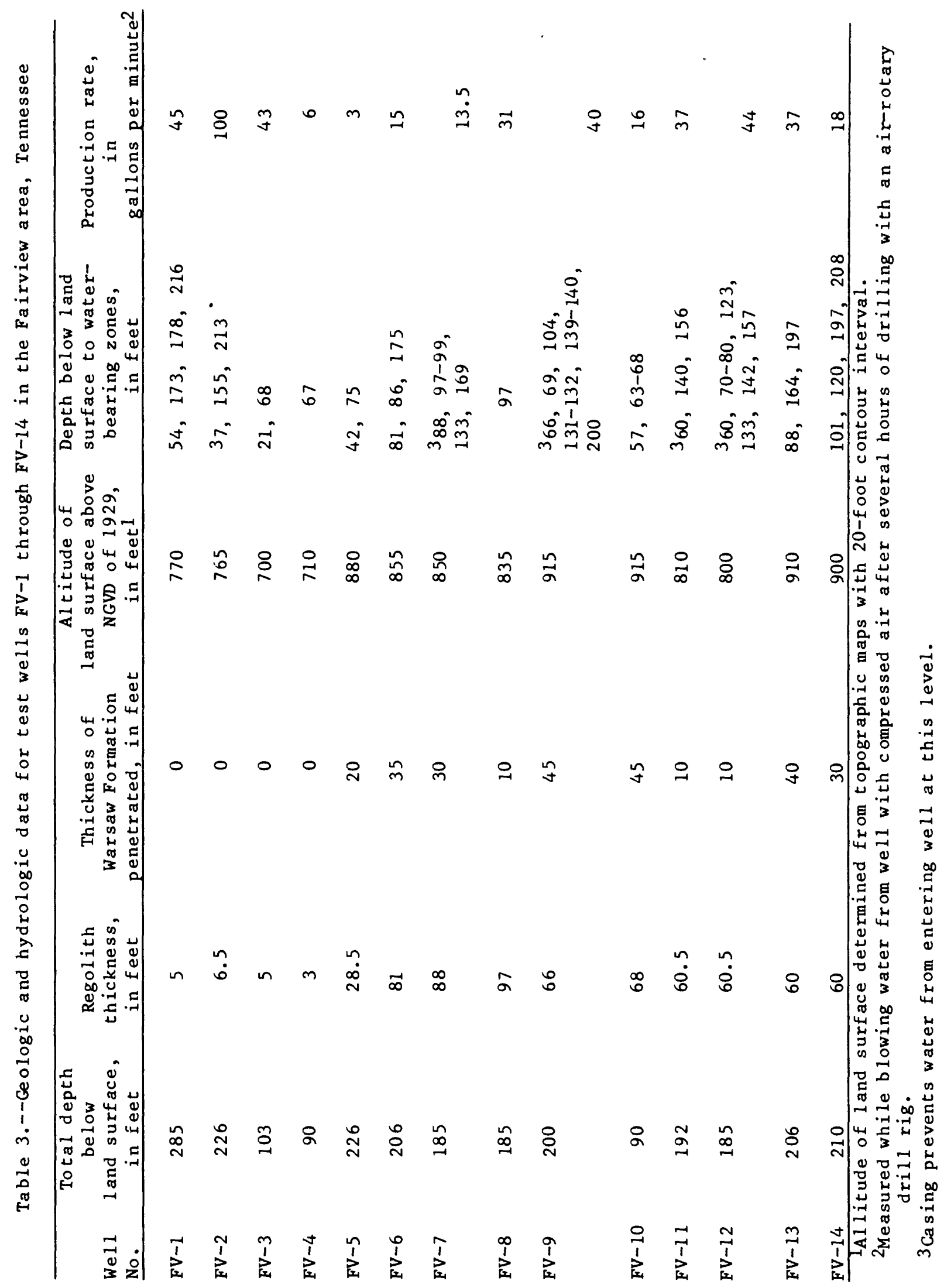




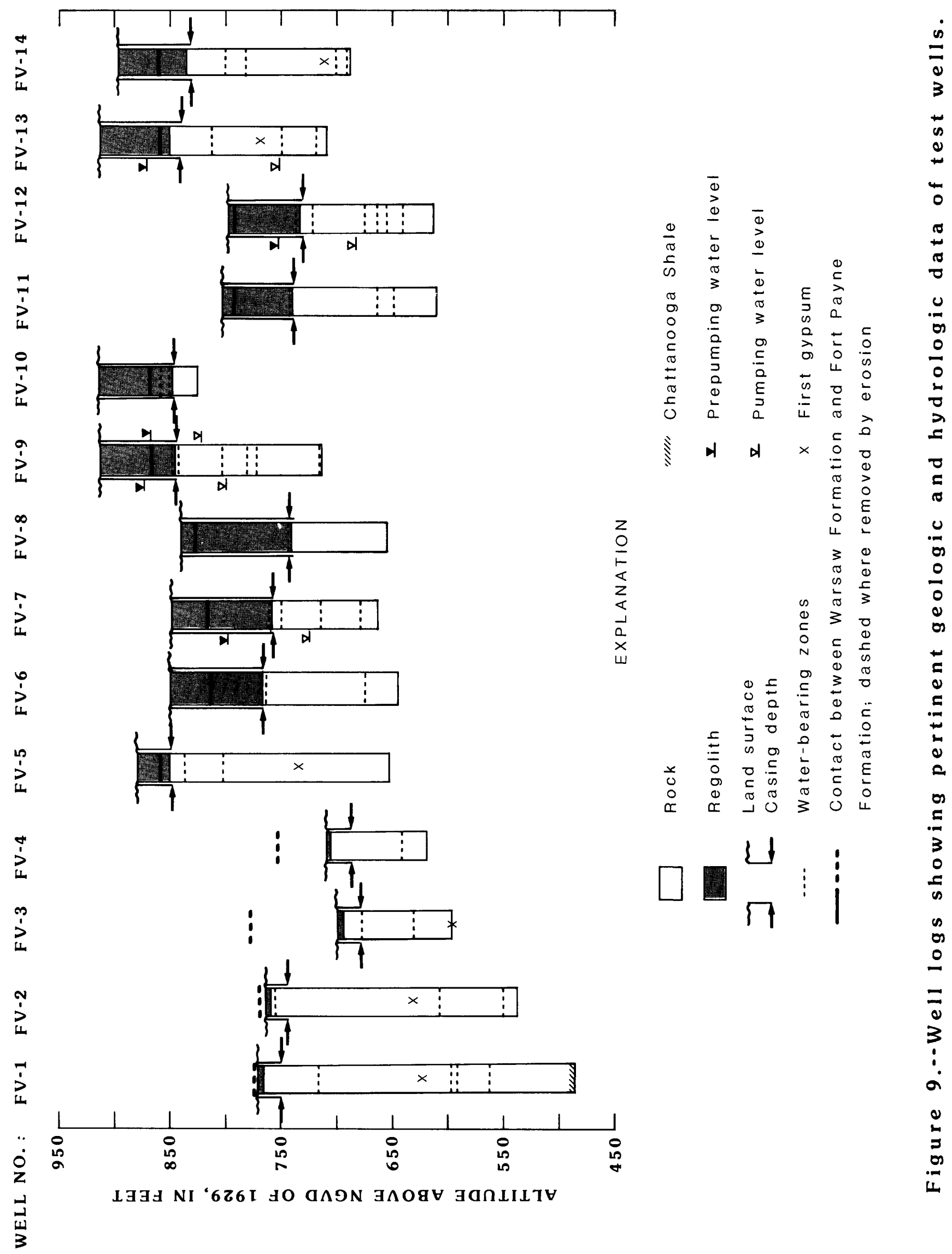




\section{Discussion of Test-Well Results}

The occurrence of ground water in the regolith and bedrock and the yields of test wells in the Fairview a rea are significantly different from occurrence and yields elsewhere in the Highland Rim of Tennessee. These differences emphasize the control of geology and weathering history upon occurrence and yields in the Fairview area. For example, figure 10 (left side) shows a sequence of regolith and rock typical of what occurs in the Fairview area. The regolith, which ranges in thickness from a few feet to about 100 feet, consists largely of clay or clay-sized particles. However, the regolith characteristically has beds and lenses of chert, especially near the bedrock contact. A zone of water-bearing broken rock or chert rubble is present in the lower part of the regolith in FV-8 and FV-9 only.

The Warsaw Formation has been weathered to clay regolith. The uppermost part of the Fort Payne Formation consists of cherty, mediumgrained 1 imestone. The middle and lower part of the Fort Payne Formation is dark-gray, dolomitic siltstone or quartzose siltstone. The gray siltstone contains sporadic occurrences of brown, weathered material having a thickness as much as several feet. This weathered material is a porous, fossiliferous silica residue. It yields little or no water to wells. This weathered material seems to be replaced in nearby wells by water-bearing openings at the same stratigraphic horizon. In most cases, the waterbearing openings yield between a few gallons per minute and a few tens of gallons per minute to wells.

In contrast to the typical section in the Fairview area, a typical section of the Manchester aquifer as described by Burchett and Hollyday (1974) for the southern part of the eastern Highland Rim is shown on the right side of figure 10. Clay-sized silica residue derived from the Fort Payne Formation occurs at land surface, but grades downward to a cherty clay and finally to a coarse, chert rubble zone at the top of bedrock at a depth of about 70 feet. Solution openings in the upper part of the bedrock collect water seeping down from the regolith. In the Manchester area only about 20 feet of cherty limestone remain above the Chattanooga Shale. Significant water-bearing openings rarely occur beneath the shale. Test wells penetrating 5 to $10 \mathrm{feet}$ of chert rubble and several solution openings in rock produce several hundred gallons per minute. Where the rubble is thinner or absent, wells produce less.

The contrast in yield between wells in the Fairview area and wells in the Manchester area may be due in part to the composition of the regolith and bedrock. The abundance of clay in the regolith at Fairview reduces the permeability of the regolith, and the large quantity of water in storage in the regolith consequently drains very slowly to the wells or to the underlying water-bearing openings in rock. The weathering of the siltstone in the Fort Payne Formation in the Fairview a rea produces large quantities of insoluble residue that also reduces the permeability of the weathered zones in the bedrock. The rate of development of water-bearing openings in the bedrock in the Fairview area is apparently so slow that the openings spread only several hundreds of feet laterally before being overtaken with time by the downward development of the regolith. 


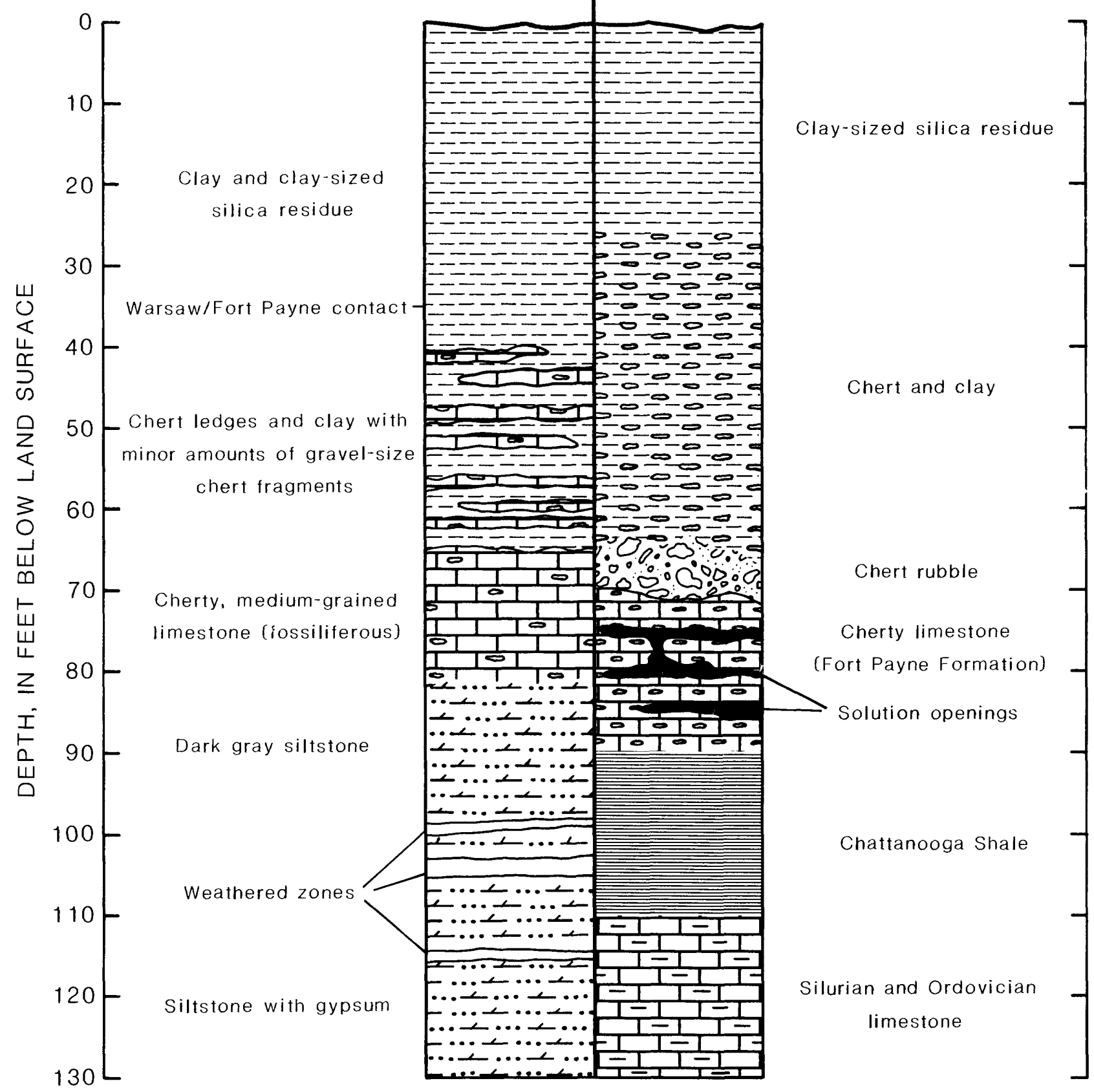

Figure 10.--Comparsion of the typical section of materials penetrated by wells in the Fairview area with the Manchester aquifer as described by Burchett and Hollyday (1974). 


\section{AQUIFER TESTS}

\section{Eight-Hour Tests}

Three of the 14 test wells were pumped for 8 hours each to determine their specific capacities and to determine the response of the waterbearing openings to pumping stress.

Well FV-7 was pumped at about $20 \mathrm{gal} / \mathrm{min}$ ( $\mathrm{fig} .11$ ). Drawdown at the end of the test was 69.77 feet, giving a specific capacity of 0.3 (gal/min)/ft (gallons per minute per foot of drawdown). The test began at 0900 hours on February 16, 1980, when the well initially produced slightly muddy water; the water subsequently cleared within the first 6 minutes. An hour later, while the pumping rate remained constant, the water became slightly muddy again and the rate of drawdown decreased significantly. The water level at this time was about 97 feet below the measuring point. A 2-foot thick crevice, the shallowest significant water-bearing opening below land surface which contributed nearly half the yield of the well at the time it was drilled, is located at that depth. At 1230 hours, the rate of drawdown increased. The water level was then at or below the bottom of this opening. Some recovery, probably because of flushing of residual clay from the water-bearing openings, took place from 1415 to 1515 hours, but at the end of the test, the water level was at its lowest point. One minute after the pump was turned off, the water level recovered to the shallowest significant water-bearing opening once again. One hour after the pump was turned off, the water level had returned to 4.14 feet below the prepumping leve1. During the test, the maximum drawdown in observation well FV-6, 300 feet to the northwest, was 1.88 feet. The pumping had no apparent effect on water levels in observation we11 FV-8, 600 feet to the east.

In a test of another well, FV-9 was pumped at $47 \mathrm{gal} / \mathrm{min}$ for 8 hours (fig. 12). Drawdown at the end of the test was 77.72 feet, giving a specific capacity after 8 hours of $0.6(\mathrm{ga} / \mathrm{min}) / \mathrm{ft}$. The pump was turned on at 0830 hours on February 14, 1980. As would be expected in pumping a laterally-extensive aquifer, the water level declined rapidly at $f$ irst and then declined more slowly with time to the end of the test. The water was clear at the beginning of the test but became slightly turbid at about 0850 hours; it was clear 40 minutes 1 ater. One minute after the pump was turned off, the water level had returned to 57.04 feet below the prepumping level. Eighty minutes after the pump was turned off, the water level had recovered to 21.96 feet below the prepumping level.

Observation well FV-10, only 37 feet away from the pumped wel1, showed little effect from pumping FV-9. The maximum drawdown was 2.14 feet and occurred at 1230 hours. Obviously, there must be restricted hydraulic connection between the water-bearing openings at the two wells. FV-9 penetrates five openings in bedrock; a sixth opening at the base of the regolith was cased-out. FV-10 on the other hand derives its total yield from the regolith. The 1 imited drawdown in FV-10 may indicate that some of the water pumped from FV-9 may be water coming from storage in the overlying regolith. Following 1230 hours ( 4 hours before the pump was turned off), the water level began recovering in $F V-10$. This recovery in $F V-10$ prior to the end of the test is believed to be a result of recharge to the regolith derived from pumped water dumped onto the ground at FV-9. If so, either the water moved 


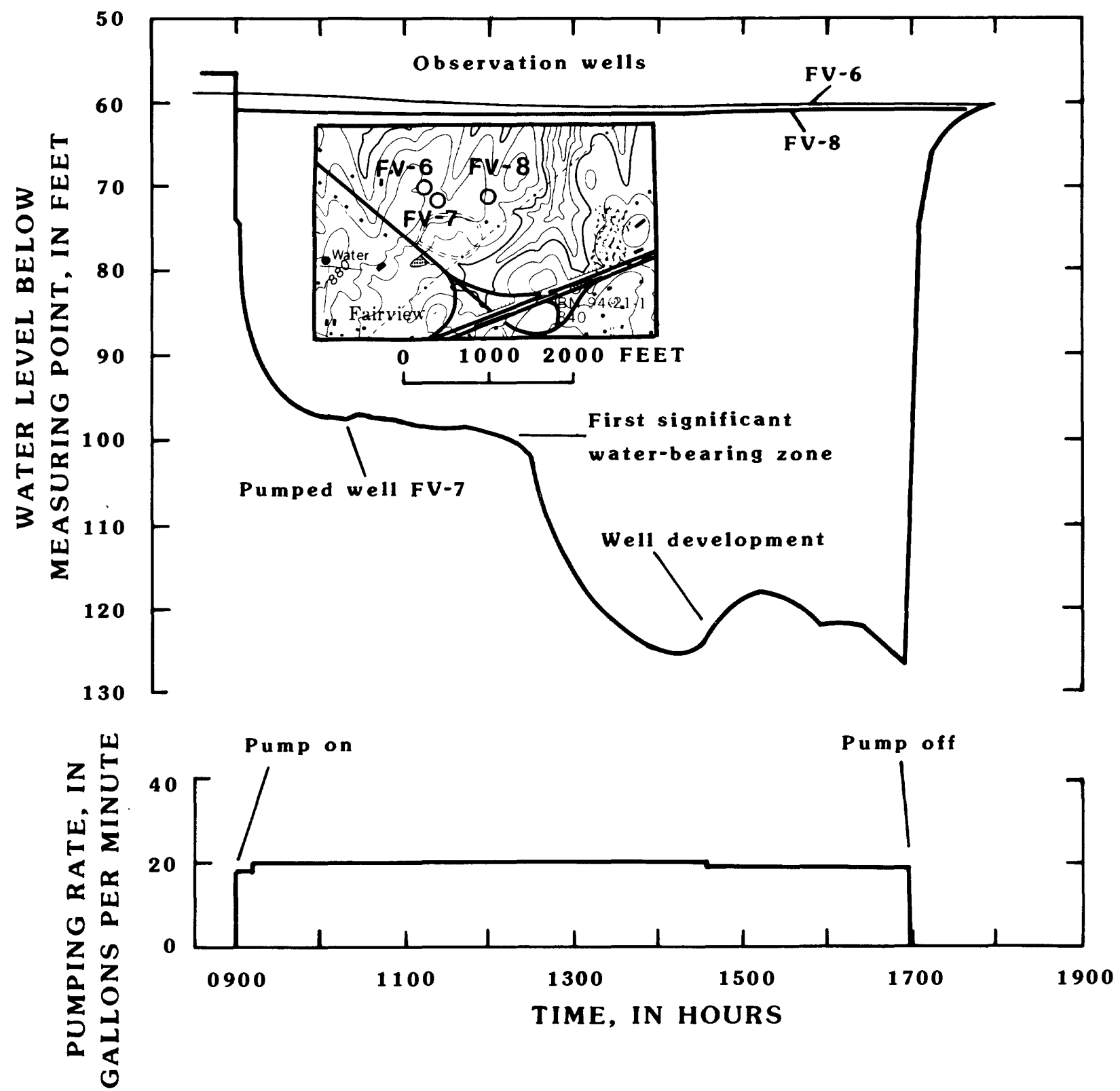

Figure 11.--Water level and pumping rate during test of well FV-7. 


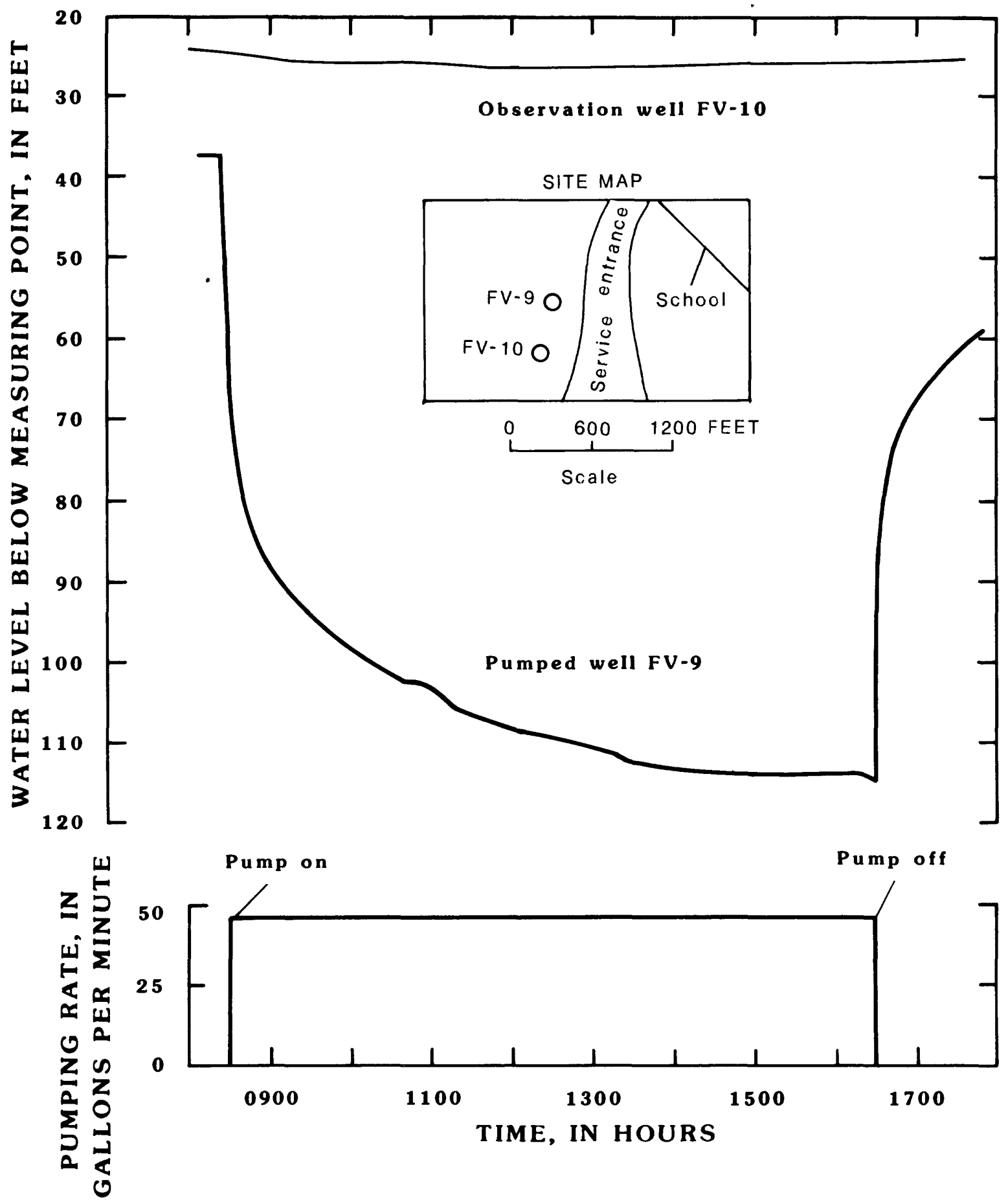

Figure 12.--Water level and pumping rate during the 8-hour test of well Fv-9. 
down 25 feet in 4 hours through the clay to the water table in the regolith or it may have leaked down the side of the casing in FV-9 and directly recharged the regolith, noticeably affecting water levels in FV-10.

In a third test, well $\mathrm{FV}-12$ was pumped at the rate of $40 \mathrm{gal} / \mathrm{min}$ ( $\mathrm{fig}$. 13). The test began at 0900 hours on March 5, 1980, and drawdown after 8 hours was 69.96 feet giving a specific capacity of 0.6 (gal/min)/ft. The rate of water-level decline decreased steadily with time. The water was clear throughout the test. One minute after the pump was turned off, the water level had recovered to 48.79 feet below the prepumping level. One hour after pumping stopped, the water level had recovered to 27.18 feet below the prepumping level; the next hour it rose another 5.82 feet.

The observation wel1 FV-11, which is 350 feet to the southeast, was affected significantly by the pumping of well FV-12. When the pump was turned on, the water level in the observation well declined 0.36 foot in the first minute; total drawdown at the end of the 8 hours was 38.83 feet.

\section{Seventy-two-Hour Tests}

Two of the test wells were pumped for 72 hours each. Well FV-9 was pumped at an average rate of $55 \mathrm{gal} / \mathrm{min}$ (fig. 14). Drawdown at the end of the test was 50.08 feet, giving a specific capacity of $1.1(\mathrm{gal} / \mathrm{min}) / \mathrm{ft}$ after 3 days. The test began at 1000 hours on March 9, 1981. Discharge was monitored closely and maintained at a fairly constant rate, with two notable exceptions. The first exception occurred at 1830 hours March 9 when the water became turbid. Discharge decreased from $55 \mathrm{gal} / \mathrm{min}$ to 30 gal/min. The second exception occurred at 2120 hours when the drive belt on the generator broke; pumping was resumed at 2145 hours at an initial rate of more than $70 \mathrm{gal} / \mathrm{min}$. Discharge remained relatively constant at about $60 \mathrm{gal} / \mathrm{min}$ for the remainder of the test. The water level remained relatively constant after 0800 hours on March 10 at about 90 feet below the measuring point ( $f$ ig. 14). Some minor fluctuations in water level may have been caused by flushing of residual silt and clay from the water-bearing openings. One minute after pumping stopped, the water level had recovered to 77.33 feet, which is 37.84 feet below the prepumping leve 1 . After 90 minutes, the water level was at $54.63 \mathrm{feet}$, or 15.14 feet below the prepumping level.

During this test, maximum drawdown in observation wel1 FV-10, was 13.97 feet, at least six times more drawdown than during the 8-hour test of FV-9 when the pumping rate was only about 15 percent less. During drilling, solution openings which did not contain water were penetrated at 83 feet in FV-9 and 84 feet in FV-10. Flushing of these openings by water moving very rapidly to the well during a step-drawdown test, performed prior to the second aquifer test, could cause an increase in the hydraulic connection between these wells which could explain both the increase in drawdown in FV-10 and the increase in specific capacity in FV-9. Observation we11 FV-14 is 530 feet from FV-9 and responded to pumping in well FV-9. The water level in FV-14 declined 2.87 feet in the first hour. Maximum drawdown was 13.91 feet. The main water-bearing opening, which is probably connected to the deeper opening in FV-9, is at 197 feet below 1 and surface. Pumping FV-9 had little effect on water levels in FV-13, which is 1,260 feet to the northeast. Maximum drawdown in FV-13 was 2.33 feet after 72 hours. 


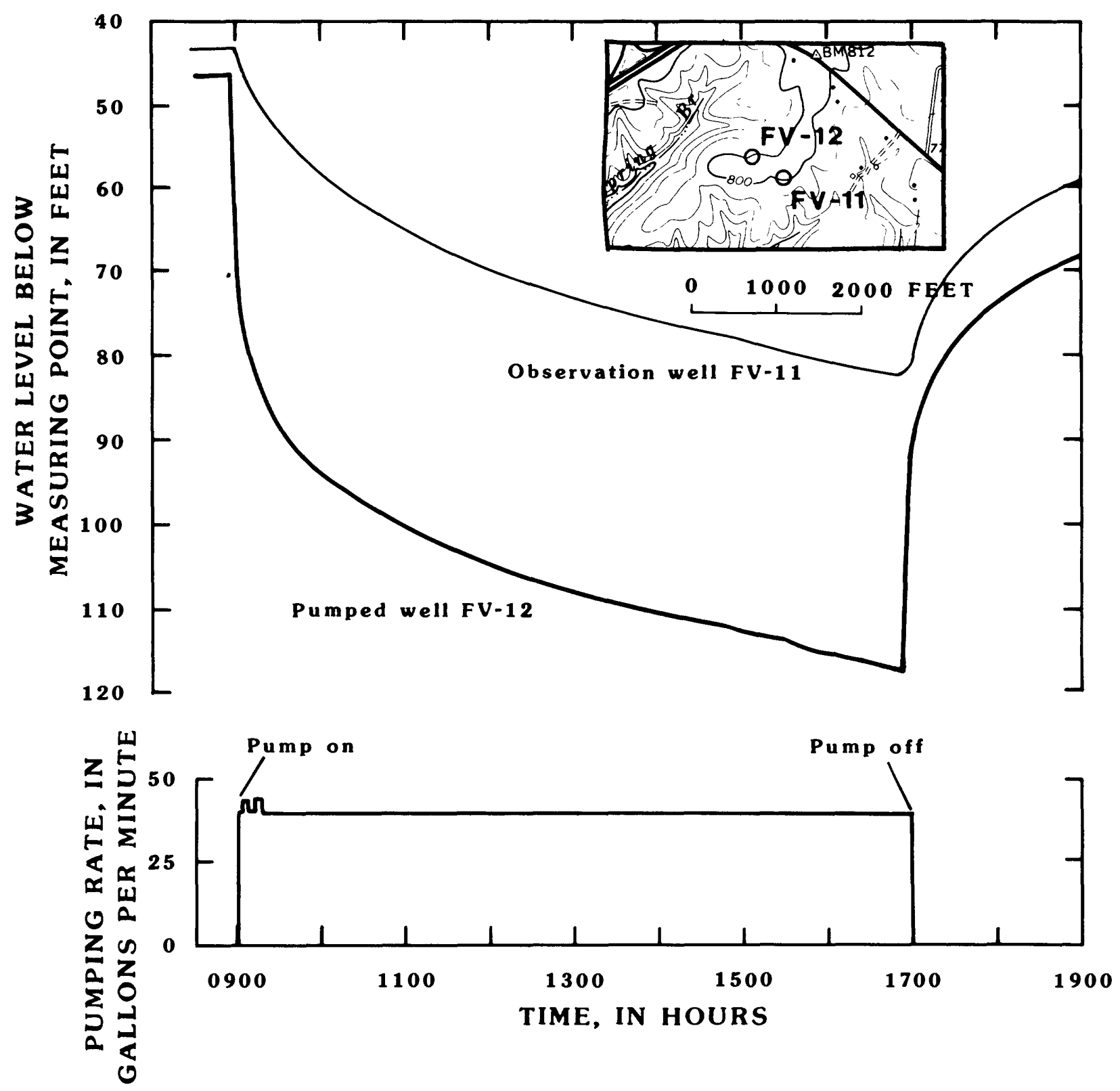

Figure 13.--Water level and pumping rate during test of well FV-12. 

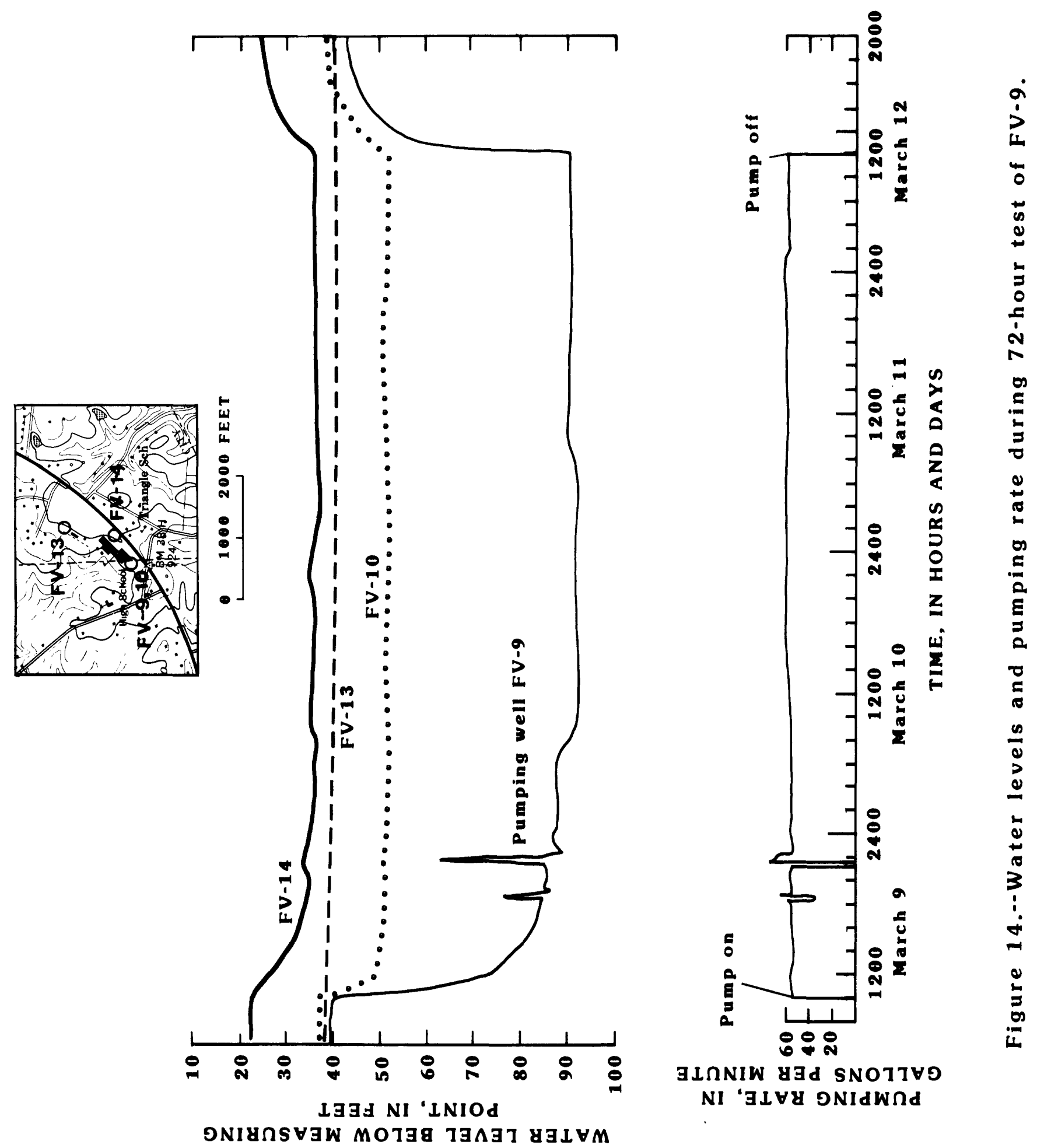
The relation between drawdown and distance at two times during the test is shown in figure 15. Assuming that the drawdown after 2,000 minutes at FV-14 is representative of drawdown in an idealized aquifer (confined, homogeneous, isotropic, and of infinite areal extent), then the measured drawdowns after 2,000 minutes of pumping are much greater than would be expected at FV-9 and much less than would be expected at FV-13 when compared to the drawdowns after 20 minutes of pumping. The 1 ack of drawdown at FV-13 implies that the water-bearing openings in FV-9 have poor hydraulic connection with water-bearing openings in FV-13. The water being pumped is coming from some direction other than from FV-13, perhaps from sources closer to the pumped well.

During an aquifer test at well FV-13, pumping began at 1000 hours on March 16, 1981 (fig. 16). The average discharge was $43 \mathrm{gal} / \mathrm{min}$ with a final drawdown of 121.16 feet, giving a specific capacity of 0.4 (gal/min)/ft after 3 days. With an initial discharge of $60 \mathrm{gal} / \mathrm{min}$, water levels in the pumped well reached 192 feet below the measuring point after 585 minutes. This was only 2 feet above the pump intake, and discharge was reduced to $40 \mathrm{gal} / \mathrm{min}$ for the remainder of the test. Discharge and water levels remained relatively constant for the remainder of the test with the exception of three brief fluctuations corresponding to times when adjustments were made to keep the long-term discharge constant. One minute after the pump was turned off, the water level had recovered to 134.41 feet. After 6 hours the water level was at 82.03 feet, stil1 42.40 feet below the prepumping water level. While the observation wells responded to pumping, drawdown in these wells was unexpectedly small (fig. 16). There was a maximum drawdown of 1.6 feet in FV-10, which is 1,290 feet southwest of FV-13; 2.5 feet in FV-9, which is 1,260 feet southwest of FV-13; and 4.5 feet in FV-14 which is 830 feet south of FV-13. Little, if any, response resulted from reducing the pumping rate from 60 to $40 \mathrm{gal} / \mathrm{min}$. It seems that the water-bearing openings in FV-13 have poor hydraulic connection with water-bearing openings in these observation wells.

\section{Discussion of Aquifer Tests}

The aquifer tests were made for three reasons: (1) to determine the hydraulic properties of the aquifer, (2) to determine the performance of the well, and (3) to determine the water-level response of the water-bearing openings at some distance from the pumped well. The hydraulic properties are needed to predict the response of the aquifer to different development and management schemes. Performance of the well needs to be known to design production wells. Areal distribution of water-level changes in response to pumping the water-bearing openings needs to be known to estimate aquifer geometry and the amount of water in storage available for development.

In order to determine the hydraulic properties of the aquifer by pumping a well and applying analytical equations to the data, many conditions must be satisfied. Some of the conditions that were not satisfied in some of these tests are: (1) the geometry of the aquifer, confining beds, and water sources must be known prior to the test, and measurement sites must be located accordingly; (2) the flow of the well must be kept constant; (3) the flow to the well must come from a single, laterallyextensive water-bearing opening; and (4) there can be no development of the 


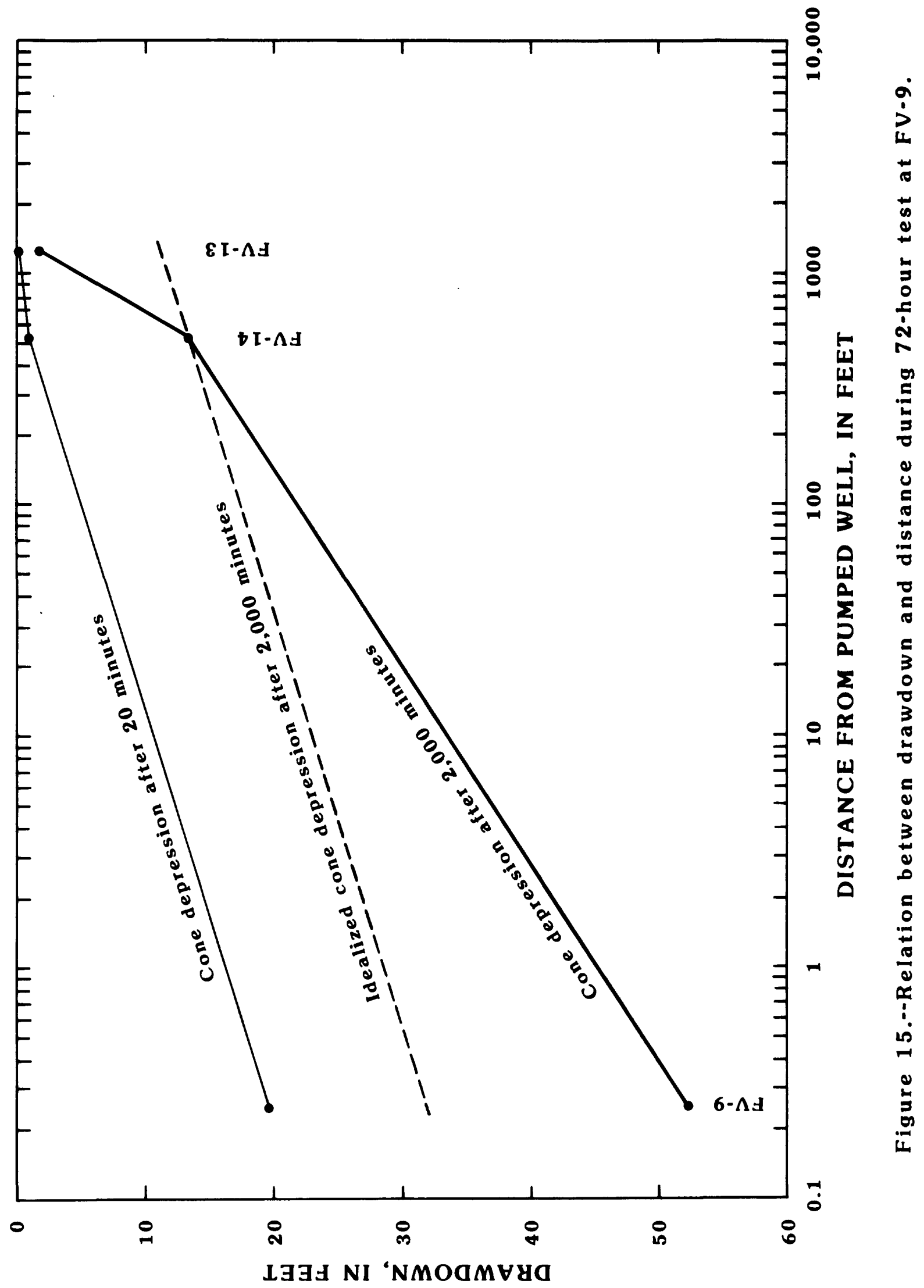




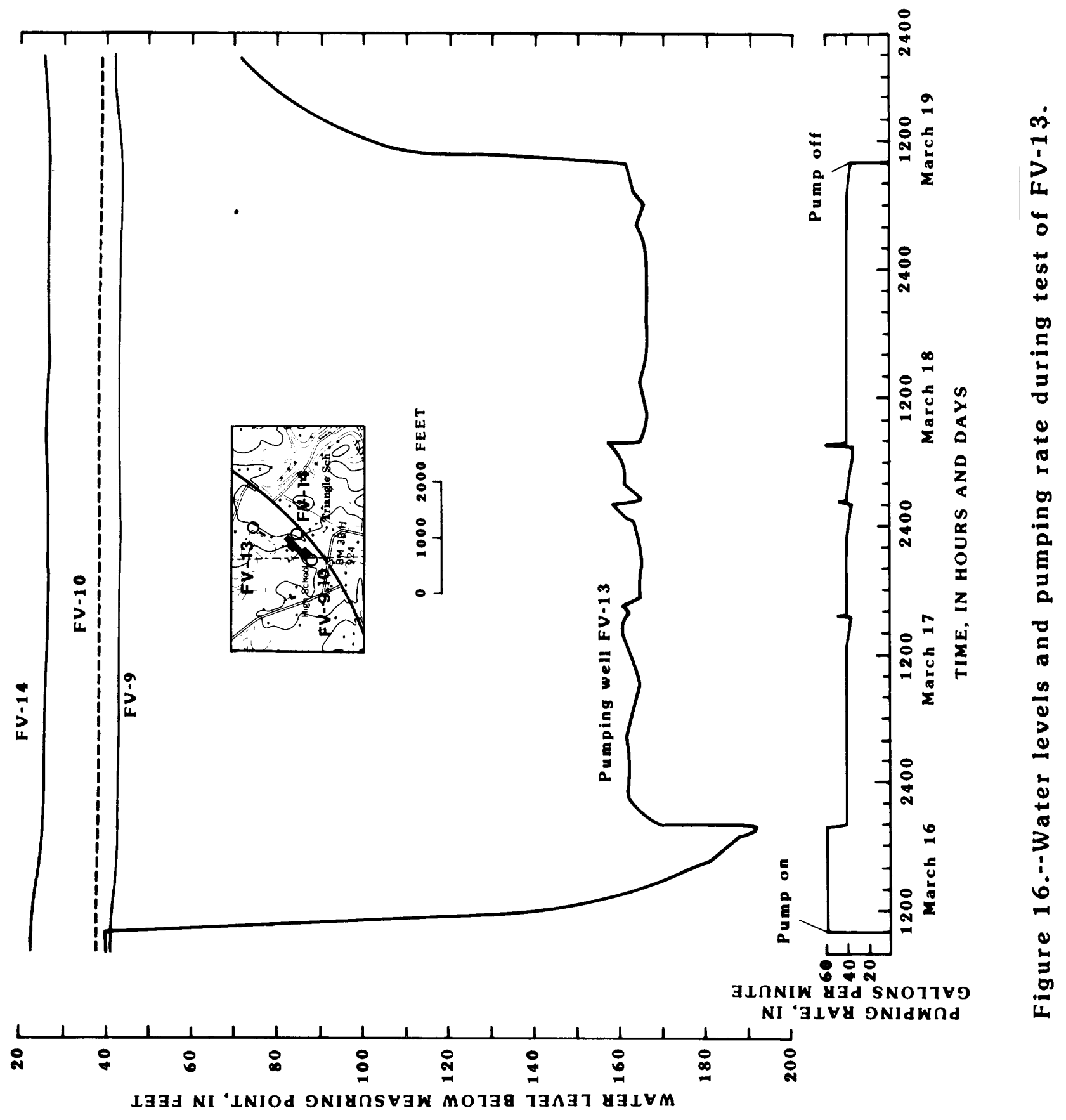


aquifer away from the well bore. The unsatisfied conditions make it difficult to calculate a reliable set of hydraulic properties for the aquifer.

Although conditions were not adequate for determining the hydraulic properties of the aquifer, the test results provide an estimate of the performance of the pumped wells ( $t a b l e ~ 4)$. The specific capacities range from 0.3 to 1.1 gallons per minute for each foot of drawdown. The greatest drawdown that is available without dewatering a significant water-bearing opening can be determined by subtracting the prepumping water level from the corresponding depth to the shallowest significant opening. This value is listed as available drawdown in table 4. The potential yield of the well for the given pumping duration may be estimated by multiplying the specific capacity by the available drawdown. The resulting estimates of potential yield range from $10 \mathrm{gal} / \mathrm{m}$ in for FV-7 to $180 \mathrm{gal} / \mathrm{min}$ for FV-9.

However, the well production is not directly proportional to the drawdown. Figure 17 shows that although FV-9 will produce $20 \mathrm{gal} / \mathrm{min}$ with 8.3 feet of drawdown after one-half hour of pumping, it will not produce 60 $\mathrm{gal} / \mathrm{min}$ with three times this amount of drawdown. Therefore, the values of potential pumping rate in table 4 should be regarded as approximate upper limits on what the wells could yield for the given duration of pumping.

The test results indicate that there is a small degree of lateral as well as vertical continuity of the water-bearing openings that make up the aquifer. It seems unlikely that the discharge of the pumped wells could be maintained by a horizontal flow of water coming laterally (or radially) to the well from distances no greater than 600 feet as implied in the relation between drawdown and distance for the 72-hour test of FV-9 (fig. 15). It is more likely that the relatively small ground-water yields to wells at Fairview, compared to Manchester, are being derived from vertical leakage from the overlying regolith and from overlying and underlying weathered zones in rock, throughout the area of influence of the pumped well.

The aquifer in the Fairview area is conceived to be a combination of water-saturated clay regolith and several water-bearing openings partly filled with weathered material in the upper 200 feet or so of otherwise dense rock. The hydraulic properties of the aquifer are different from well to well depending on the grain size of the material in the regolith and the number, size, and openness of water-bearing openings in the rock penetrated by the well. Vertical leakage of water downward from the regolith must be a significant factor in the production of water by wells and probably influences the areal extent of the effects of pumping in each well.

\section{GROUND-WATER QUALITY}

Water produced from water-bearing openings above the gypsum horizons in the Fort Payne Formation, as in the case of FV-7, FV-9, and FV-12, usually has a specific conductance less than $500 \mu \mathrm{mho} / \mathrm{cm}$ (micromhos per centimeter at $25^{\circ}$ Celsius) (fig. 18). Dissolved solids are less than 300 $\mathrm{mg} / \mathrm{L}$ (milligrams per liter) (table 5). The water is hard to very hard, ranging from 130 to $220 \mathrm{mg} / \mathrm{L}$ as $\mathrm{CaCO}_{3}$. With the exception of occasional 


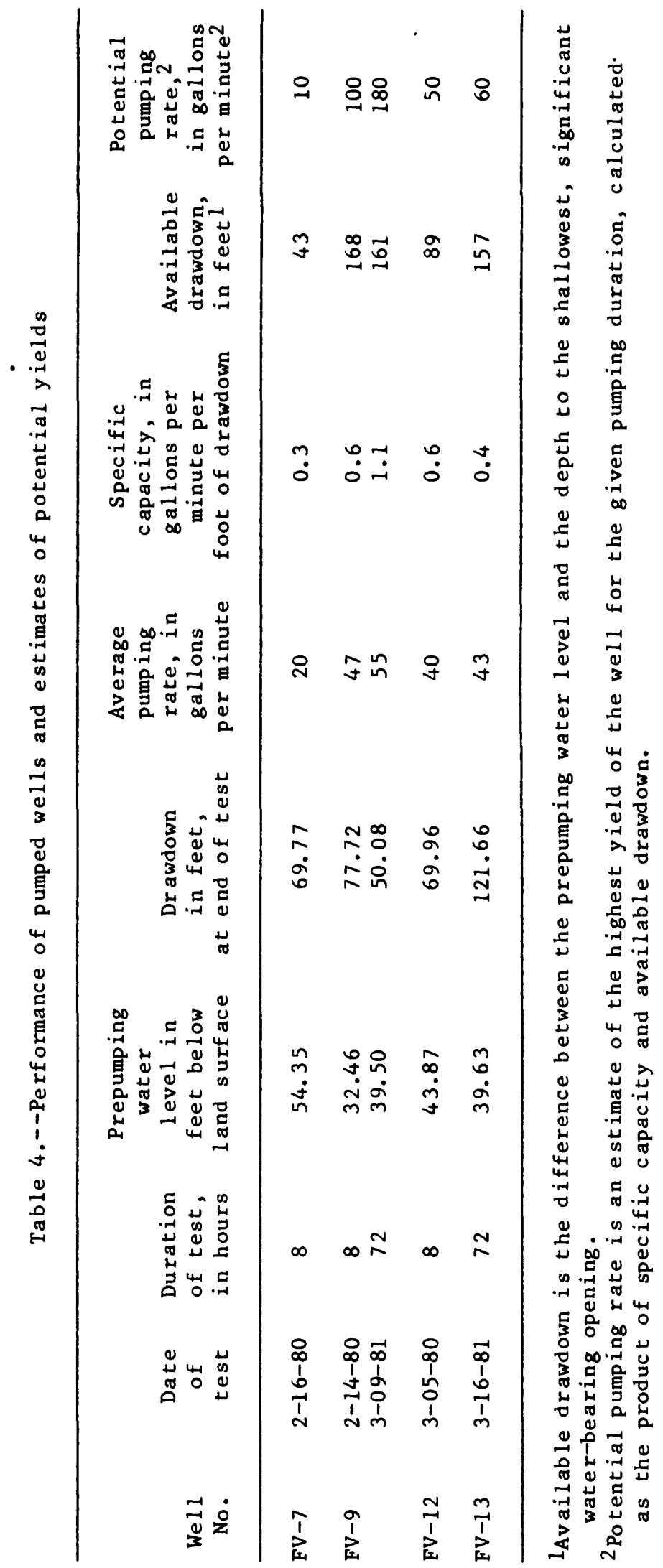




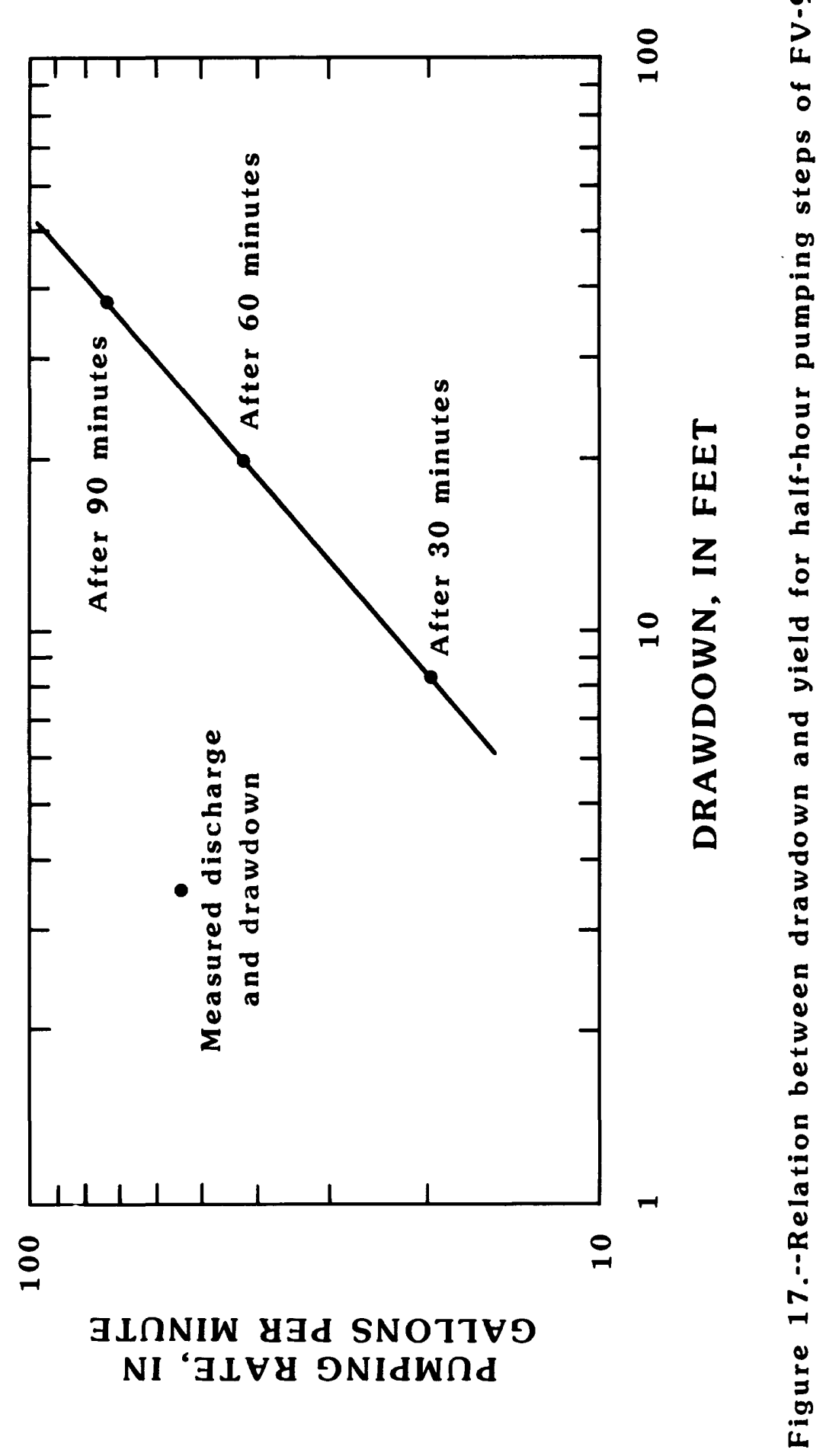



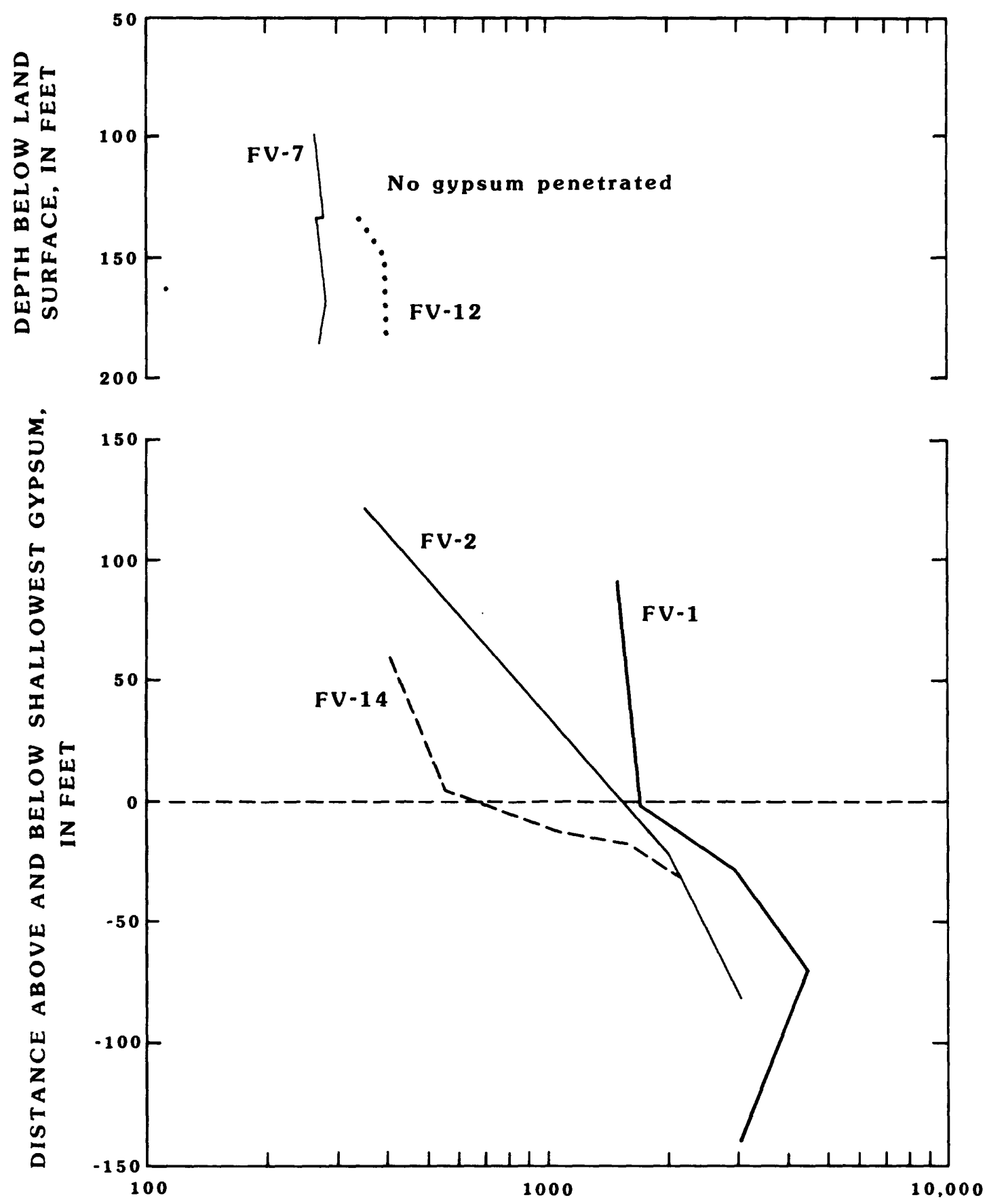

SPECIFIC CONDUCTANCE, IN MICROMHOS PER CENTIMETER AT $25^{\circ}$ CELSIUS

Figure 18.--Relation between specific conductance and occurrence of gypsum in test wells. 


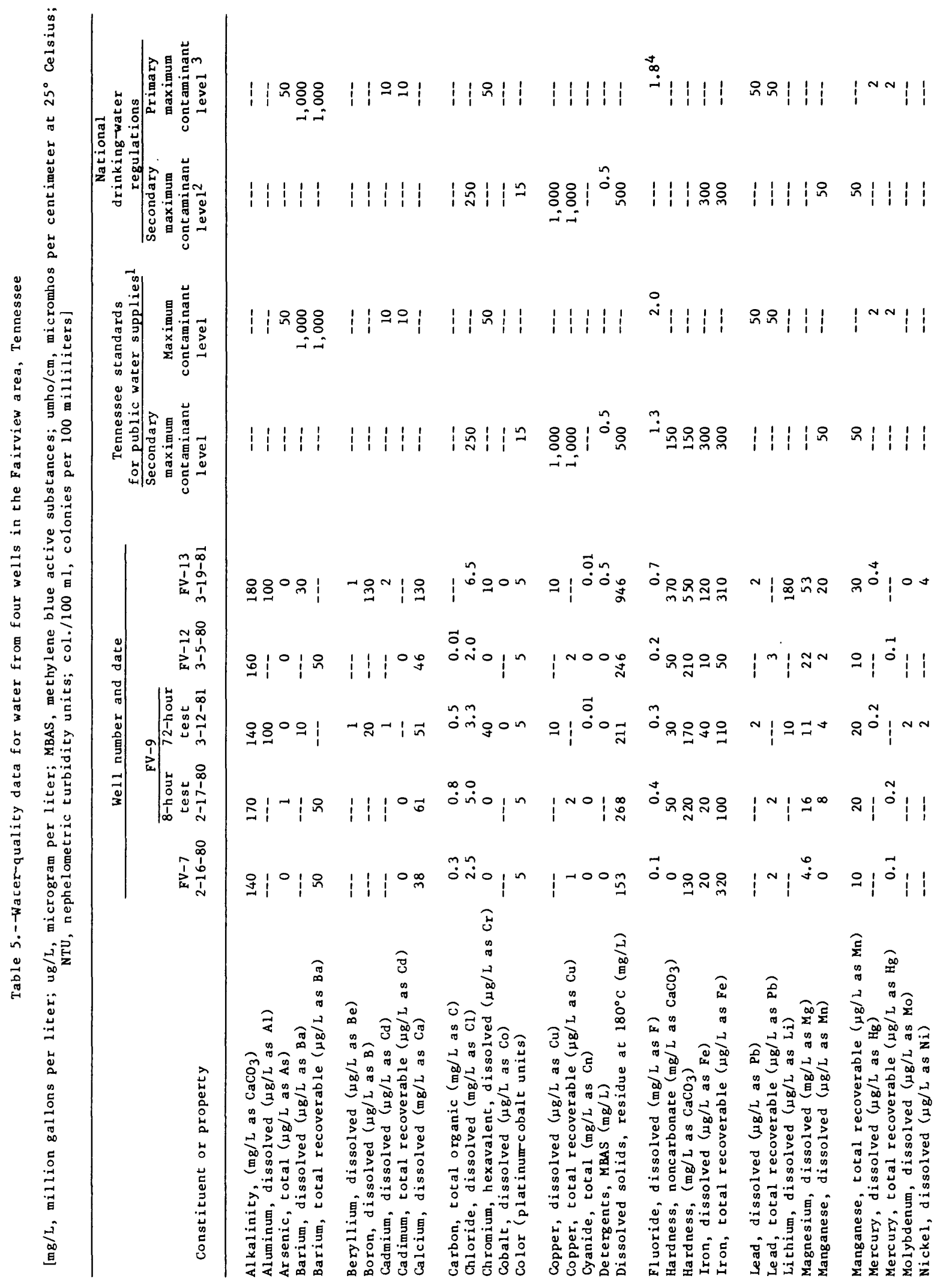




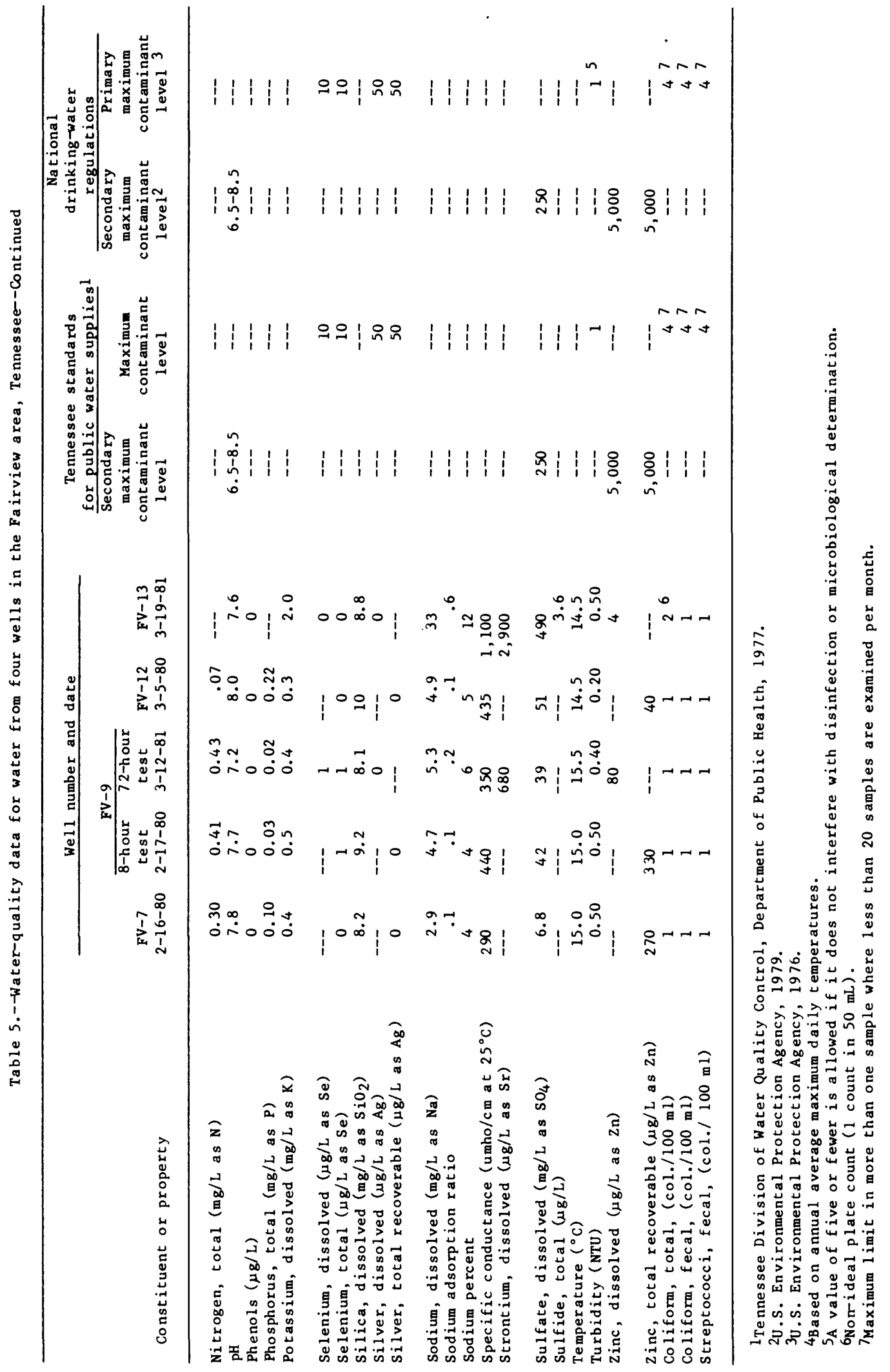


occurrences of moderately large concentrations of total recoverable iron, the water, without treatment, meets the standards of the Tennessee Department of Public Health and the U.S. Environmental Protection Agency for finished drinking water (table 5).

Water produced from water-bearing openings below the shallowest occurrence of gypsum, as in the case of FV-1, FV-2, and FV-14, has a specific conductance greater than $1,000 \mu \mathrm{mho} / \mathrm{cm}$ (fig. 18). Dissolved solids exceed $900 \mathrm{mg} / \mathrm{L}$ and sulfate may be as great as $490 \mathrm{mg} / \mathrm{L}$ (table 5). In the case of water from FV-13 which also produces water from openings below the shallowest occurrence of gypsum, concentrations of dissolved solids, sulfate and total iron, without treatment, do not meet the standards of the Tennessee Department of Public Health and the U.S. Environmental Protection Agency for treated drinking water (table 5).

\section{SUMMARY AND CONCLUSIONS}

1. The Fairview area is underlain by 1 imestone, dolomite, and siltstone. The Warsaw Formation caps the higher hills and is underlain by the Fort Payne Formation. The regolith and the upper part of the Fort Payne Formation are the principal aquifer in the area.

2. Springs in the Fairview a rea generally discharge from the regolith and upper 100 feet of the Fort Payne Formation indicating ground-water movement within this interval. Discharge measured from springs in the area ranged from less than $1 \mathrm{gal} / \mathrm{min}$ to about $300 \mathrm{ga} 1 / \mathrm{min}$. Horntavern and Morgan Springs have the largest and steadiest discharge.

3. Significant gains in streamflow occur where the streams cut through the regolith and upper part of the Fort Payne Formation. Contribution of water diminishes as the streams cut down into the lower Fort Payne indicating greater ground-water contribution from the upper part of the formation.

4. Based on the low-flow measurements of streams, the recharge rate to the ground-water system is estimated to be as much as 0.9 (Mgal/d)/mi2 in the uplands. Recharge occurs in the uplands and discharge occurs along streams and at springs in the upland valleys.

5. Supply wells that produce $20 \mathrm{gal} / \mathrm{min}$ or more a re generally on slopes. They obtain water in most cases, from between 50 and 150 feet below land surface. Supply-well records, as reported by drillers, are reasonably accurate indicators of ground-water potential in this area. The average reported yield in the area is $13 \mathrm{gal} / \mathrm{min}$, whereas the average yield of 14 test wells is $32 \mathrm{gal} / \mathrm{min}$. The maximum reported yield is $70 \mathrm{gal} / \mathrm{min}$, whereas the maximum yield from a test well is 100 gal/min. The specific capacity of test wells ranged from 0.3 to 1.1 ( $\mathrm{gal} / \mathrm{min}) / \mathrm{ft}$.

6. Ground water occurs in weathered zones in the coarse-grained 1 imestone and in the fine-grained limestone or dolomite in the upper part of the Fort Payne Formation. These water-producing $z$ ones do not appear to be 
the clean solution openings generally associated with limestone in Middle Tennessee. Many are filled or partially filled with clay-sized chert residuum. It is likely that the yields of wells may be enhanced by intensive surging and development of wells to open these clay-filled passages in the bedrock.

7. The hydraulic properties of the aquifer are different from well to well depending on the grain-size of the material in the regolith and the number, size, and openness of water-bearing openings in the rock penetrated by the well.

8. Aquifer tests of four wells indicate that the specific capacities of these wells ranged from 0.3 to 0.6 ( $\mathrm{gal} / \mathrm{min}) / \mathrm{ft}$ after 8 hours of pumping at 20 to $47 \mathrm{gal} / \mathrm{min}$, and 0.4 to 1.1 (gal/min)/ft after 72 hours of pumping at 43 to $55 \mathrm{gal} / \mathrm{min}$. The water-bearing openings in the bedrock are not continuous over great distance. The test results indicate that there is practically no association in water-level fluctuations in wells located farther than about 600 feet apart.

9. The mineral content of ground water increases greatly below the shallowest occurrence of gypsum, approximately 100 feet below the top of the Fort Payne Formation. The water has a specific conductance greater than $1,000 \mu \mathrm{mho} / \mathrm{cm}$, has dissolved solids greater than 900 $\mathrm{mg} / \mathrm{L}$, and has sulfate as high as $490 \mathrm{mg} / \mathrm{L}$.

10. With the occasional exception of total recoverable iron, raw water produced from water-bearing openings above the shallowest occurrence of gypsum meets the regulatory standards for treated drinking water (Tennessee Division of Water Quality Control, 1977; and U.S. Environmental Protection Agency, 1979). 


\section{REFERENCES}

Burchett, C. R., 1977, Water resources of the upper Duck River basin, central Tennessee: Tennessee Division Water Resources, Water Resources Series No. 12, 103 p.

Burchett, C. R., and Hollyday, E. F., 1974, Tennessee's newest aquifer: Geological Society of America Abstract with Programs, v. 6, no. 4, p. 338 .

Marcher, M. V., Bingham, R. H., and Lounsbury, R. E., 1964, Ground-water geology of the Dickson, Lawrenceburg, and Waverly areas in the western Highland Rim, Tennessee: U.S. Geological Survey Water-Supply Paper $1764,50 \mathrm{p}$.

Miller, R. A., and Wilson, C. W., 1973, Geologic map and mineral resources summary of the Kingston Springs quadrangle, Tennessee: Tennessee Division of Geology GM305-SE, scale 1:24,000.

Moore, G. K., and Bingham, R. H., 1965, Availability of ground water in the western Highland Rim of Tennessee: Journal of the Tennessee Academy of Science, v. 40, no. 1, p. 22-26.

Moore, G. K., and Wilson, J. M., 1972, Water resources of the Center Hil1 Lake region, Tennessee: Tennessee Division of Water Resources, Water Resources Series No. 9, 77 p.

Parizek, R. R., and Drew, L. J., 1966, Random drilling for water in carbonate rocks: Pennsylvania State University, Water Resources Research Publication No. 3166, 22 p.

Piper, A. M., 1932, Ground water in north-central Tennessee: U.S. Geological Survey Water-Supply Paper 640, 238 p.

Rima, D. R., and Goddard, P. L., 1979, Ground-water resources in the metropolitan region of Nashville, Tennessee: prepared by U.S. Geological Survey for U.S. Army Corps of Engineers, Nashville District, Nashville, Tenn., 44 p.

Tennessee Division of Water Quality Contro1, 1977, Public Water System in Rules of Tennessee Department of Public Health - Bureau of Environmental Health Services - Division of Water Quality Control: Tennessee Department of Public Health, Bureau of Environmental Health Services, Division of Water Quality Control, Chapter 1200-5-1, 29 p.

U.S. Environmenta1 Protection Agency, 1976, National interim primary drinking water regulations: U.S. Environmental Protection Agency report EPA 570/9 - 76-002, $159 \mathrm{p}$.

1979, National secondary drinking water regulations: U.S.

Environmental Protection Agency report EPA 570/9 - 76-000, 37 p. 
White, W. A., 1960, Major folds by solution in the western Highland Rim of Tennessee [abs.]: Geological Society of America Bulletin, v. 71, no. 12, p. 2029.

Wilson, C. W., 1972a, Geologic map and mineral resources summary of the Fairview quadrangle, Tennessee: Tennessee Division of Geology GM56-NE, scale $1: 24,000$.

1972b, Geologic map and mineral resources summary of the White Bluff quadrangle, Tennessee: Tennessee Division of Geology GM305-SW, scale $1: 24,000$.

Wilson, C. W., and Lounsbury, R. E., 1972, Geologic map and mineral resources summary of the Craigfield quadrangle, Tennessee: Tennessee Division of Geology GM56-NW, scale $1: 24,000$.

Zurawski, Ann, 1978, Summary appraisals of the nation's ground-water resources - Tennessee region: U.S. Geological Survey Professional Paper 813-L, 35 p. 